\title{
Political Theology: Political Sovereign Deity in the Semitic Scriptures; The Hebrew Bible, The New Testament and The Qur'an (I)
}

\author{
NIYAZİ KAHVECİ \\ DOÇ. DR.,
}

\begin{abstract}
özet
İslam Mezhepleri Tarihi'ni küresel ilmi disiplin olarak, belki de en isabetli ifade edecek, isim "Siyasal Teoloji” olabilir. Çünkü her şeyden önce İslam Mezheplerinin tarihi, adı üzerinde olduğu gibi tarih ile, yani hadise ve pratik ile içiçedir. Hadisenin fikirsiz cerayan etmesi ve meydana gelmesi imkansızdır. Ayrıca bir realite olarak, İslam Mezhepleri'nin ekseriyetle ve ağırlıkla fikren ya da pratik olarak siyasete müdahil oldukları ve bu alanlarda fikirsel ya da pratiksel ürünler verdikleri gerçeği, yeterli araştırmalar tarafından yeterince ispat edilerek ortaya konmuştur. $\mathrm{Bu}$ tarih, aynı zamanda onların siyasal düşüncelerinin de tarihidir. İslam Mezhepleri’nin siyasal düşüncesini isabetle tespit etmek ve doğru anlayabilmek için, İslam'ın birinci kaynağı olan Kur'an'ın, dolayısıyla ve mecburen, onun, son halkasını oluşturduğu Semavi dinlerin, geriye ve kaynağa doğru giderek, Kitapları olan İncil ve Tevrat'ın siyaset düşüncesine vakıf olmamızın kaçınılmaz olduğu anlaşılmaktadır. Semavi dinlerin siyaset düşüncesinin, belki de daha sonraları beşerî (Batı) felsefesinin birinci derecedeki dayanağını ve kaynağını bize öğretecek olan konunun başlığı, "Semavi Kitaplar'da Siyasal Egemen Tanrı" dan başkası olamazdı. Bu nedenle ve aynı zamanda bir örnek olmak üzere, bu üç Kitab'ın bu düşüncesini Siyasal Teoloji disiplinin metodolojisi ile yani; fikri, tarihiyle birlikte mukayeseli, eleştirel ve analitik olarak incelemeye çalıştı.
\end{abstract}

anahtar kelimele

Siyasal Teoloji, Egemenlik, Kutsal Kitaplar, İslam Mezhepleri, Kur’an.

Political Theology emerged relatively very recently ${ }^{1}$ and is mostly concerned with political dimensions of the religions alongside with their history. In doing so it puts forward the doctrinal (creedal) changes throughout the history. History is a significant dimension of human existence. Humanbeing and history is the product of each other. That is humanbeing is history's

\footnotetext{
1 Political theology is a new movement in contemporary theology which emerged in the 1960 s. This discipline is the most important area of theology today. Political theology is a branch of both political theory and theology. It investigates, analyses, criticises and reconstructs the politics. It asses critically how political matters are incorporated into the theology. Political theology defines the political dimention of the teachings of the religions. It asks the question of whether God is political? Therefore the religious precepts need to be analysed alongside with the light of their political history. Matthias Lutz-Bachmann, Routledge Encyclopedia of Philosophy, ed. Edward Graig (London-New York, 1998), V 9; Alistair Kee, The Scope of Political Theology (Norwitch, 1978).
} 
subject and agent. As a prominent political theologian Alistair Kee has clearly depicted that, "To proceed today with dogmatics as if nothing had changed is to make ontological assumptions about God." Political theology's elaboration is dialectical and analitical since the human-god relations in the Scriptures are dialectical and analitical. Politics, theology and history are interrelated.

Political theology begins with a political term of the sovereignty, that is; "the sovereignty of God." ${ }^{3}$ Although the terminologies of "Political Authority" and "Political Power" and "Sovereignty" are interchangeably used, the terminology of the "sovereignty" has a broader meaning and encompasses all of them. Political theology also consists of the theology of revolution. Because the Scriptures described their prophets as the philosophers and the revolutionaries; who interpreted the world and changed it. With the only difference from the philosophers is that the prophets had put their ideas into practice.

Up today, even today, the divinial source of the legitimacy of the world's states' sovereignty and their constitution, and the intertwint relation of deity and religion with politics has been questioned throughout human history. From the outset of human history almost all religions are intermingled with politics. Political religions are the essence of ancient pagan religions in which there are no states without gods and no divinities without states. We even find a history of political structures within the so called "Semitic Divine Scriptures" themselves, and we find that those structures are interpreted within that history, by means of certain concepts which render the history intelligible. Within the Hebrew Bible, the source of the other two Scriptures, history is presented in various ways. These include poetry, plain narrative, parables, preaching and interpretation of events to suit one or other purpose of the authors of the books, peculiar to the history, particularly its political history of Israel. ${ }^{4}$

Our curiosity is what would come out if we look at "the Deity" of the Semitic Scriptures from the humane political standpoint. Hence this work aims at discovering the concept of the "Political Sovereignty of God" in the three Semitic Divine Scriptures of the monotheistic religions, namely; The Hebrew Bible, The New Testament and the Qur'an. This comparative and analytical work will, first of all, put forward their political dimension and secondly, the convergences and divergences in this subject-matter amongst them, and between the humane and divine sovereignty. The Scriptures are

2 Alistair Kee, A Reader in Political Theology (London, 1977), xi.

3 See for example, Carl Schmitt, Political Theology, trns. By George Schwab (2.nd ed. Massachusetts Inst. Technology), pp. 5-15.

4 Nicol Milne, "Pprophet, Priest and King and Their Effect on Religion of Israel", ABR-Nahrain, (19601961), 55-67, II/55. 
taken as a whole in such a way as to generate theology with regard to the question of political sovereignty of God. As we conceive the deity, we must think of the divine sovereignty. This depends on what the Deity is.

\section{DEITY}

Almost all the different faiths and belief systems use the terms "deity" to refer to some transcendent or transcendental power, or its attributes or manifestations in the world. ${ }^{5}$ But the usage varies significantly depending on the underlying conception of their deity that is being invoked. ${ }^{6}$ In many cases a deity is merely a power or force personified, and these powers and forces may then be extended or granted to mortal individuals. Most religions around the world, whether it is Hinduism, Judaism, Islam, or Christianity has always considered God as the supreme authority. And all the religious scriptures have considered God to have authority and wisdom, which is far superior than what any human being possesses. Hence the divinities are closely related to the transcendent forces or powers credited to them, so much so that in some cases the powers or forces may themselves be invoked independently. This leads to the second usage of the word divine (and a less common usage of divinity) to refer to the operation of transcendent power in the world. ${ }^{7}$ In monotheistic faiths, the word deity is often used to refer to the

5 For example the dharmic religions too used the terms; Bhagavan "The Opulent One", Brahman"The Great", Paramatma "The Supersoul" and Ishvara "The Controller," for God in the Vedas. A number of Hindu traditions worship a personal form of God or Ishvara, such as Vishnu or Shiva (God), whereas others worship a non-personal Supreme Cosmic Spirit known as Brahman. The Vaishnava schools consider Vishnu as the Supreme Personality of Godhead and within this tradition is the Vishnu sahasranama, which is a hymn describing the one thousand names of God (Vishnu). Shaivites consider Shiva as the Supreme God in similar way to the followers of Vaishnavism. The Supreme Ishvara of Hinduism must not be confused with the numerous deities or demigods who are collectively known as devas.

6 The root of the words of divine and divinity is literally means "Godlike" which stemmed from the Latin "Deus," cf. Dyaus that closely related to Greek "Zeus" and Deva in Sanskrit.

7

In its most direct form, the operation of transcendent power implies some form of divine intervention. For pan- and polytheistic faiths this usually implies the direct action of one god or another on the course of human events. In Greek legend, for instance, it was Poseidon (god of the sea) who raised the storms which blew Odysseus' craft off course on his return journey, and Japanese tradition holds that a god-sent wind saved them from Mongol invasion. Prayers or propitiations are often offered to specific gods of pantheisms to garner favorable interventions in particular enterprises: e.g. safe journeys, success in war, or a season of bountiful crops. Many faiths around the world - from Japanese Shinto and Chinese traditional religion, to certain African practices and the faiths derived from those in the Caribbean, to Native American beliefs - hold that ancestral or household spirits offer daily protection and blessings. In monotheisms divine intervention may take very direct forms: miracles, visions, or intercessions by blessed figures. Monotheistic faiths generally support some version of divine providence, which acknowledges that the Divinity of the faith has a profound but unknowable plan always unfolding in the world. Unforeseeable, overwhelming, or seemingly unjust events are often thrown on 'the will of the Divine' in deferences like the Muslim inshallah (as Allah wills it) and Christian 'God works in mysterious ways.' Often such faiths hold out the possibility of divine retribution as well, where the Divinity will unexpectedly bring evil-doers to justice through the 
single, supreme being central to that faith most commonly refers to the one worshipped by followers of monotheistic and monolatrist religions, whom they believe to be the sole creator and ruler of the universe. The capitalized form of noun "God" is the proper English name used for the deity of monotheistic faiths.

\section{A. Deity in the Semitic Scriptures}

Major world religions can be broadly categorized into Semitic and nonSemitic religions. Semitic religions are the religions that originated among the Semites. Major Semitic religions are; Judaism, Christianity and Islam. All these religions believe that they have been given a Divine Scripture through prophets sent from God. The three Semitic Scriptures are; Hebrew Bible (HB) $)^{8}$ for Jews, New Testament $(\mathrm{NT})^{9}$ for Christians, and for Muslims is the Qur'an. ${ }^{10}$ We will examine them in their chronological order.

conventional workings of the world; from the subtle redressing of minor personal wrongs, to such large-scale havoc as the destruction of Sodom and Gomorrah or the biblical Great Flood. Other faiths are even more subtle: the doctrine of karma shared by Buddhism and Hinduism is a divine law similar to divine retribution but without the connotation of punishment: our acts, good or bad, intentional or unintentional, reflect back on us as part of the natural working of the universe. Philosophical Taoism also proposes a transcendent operant principle — transliterated in English as tao or dao, meaning 'the way' which is neither an entity nor a being per se, but reflects the natural ongoing process of the world. See, for example Bobula Ida "The Great Stag: A Sumerian Divinity" in (Yearbook of Ancient and Medieval History 1953.

8 Since the books of the Jewish Bible were written primarily in Hebrew (with some Aramaic) the Bible of Judaism is often called "the Hebrew Bible." Another Jewish term commonly used for theie Scripture is Tanakh. Most scholars agree that the this Scripture was composed and compiled between the 11th century BC and the 2nd century BC. According to the Jewish tradition, the Tanakh consists of 24 books; 5 books of the Torah (Instruction), 8 books of the Neviim (Prophets), 11 books of the Ketuvim (Writings or Scriptures). By the 3rd century BC, Jewry was situated primarily within the Hellenistic world. Outside of Judea, many Jews may have needed synagogue readings or texts for religious study to be interpreted into Greek, producing a need for the Septuagint (LXX). Alexandria held the greatest diaspora of Jewish community of the age and was also a great center of Greek letters. Alexandria is thus likely the site of LXX authorship. The Septuagint enjoyed widespread use in the Hellenistic Jewish diaspora and even in Jerusalem. Christian name for the Hebrew Bible is Old Testament, which serves as the first division of the Christian Bible. New Testament writers, however, simply call the Old Testament the "Scriptures." Judaism does not accept the books of the New Testament as Scripture. They do not label their Bible, as the Old Testament. The designations of the Testament as "Old" and "New" seem to have been adopted after c.AD 200 to distinguish the books of the Mosaic covenant and those of the "new" covenant in Christ. For Medieval Christians the Bible was what the Europeans called the Vulgate, a Latin translation of the Old Testament.

9 The New Testament is the name given to the final portion of the Christian Bible, written after the Old Testament. It is sometimes called the Greek Testament or Greek Scriptures, or the New Covenant which is the literal translation of the original Greek. The original texts were written in Koine Greek by various unknown authors after c. AD 45 and before c. AD 140. Its 27 books were gradually collected into a single volume over a period of several centuries. See Raymond E. Brown, An Introduction to the New Testament; Burton L. Mack, Who Wrote the New Testament? (Harper, 1996). We mean by NT, the four narratives of Jesus Christ's ministry, called "Gospels," each of the Gospels narrates the ministry of Jesus of Nazareth. The Gospels are; The Gospel of Matthew, the Gospel of Mark, the Gospel of Luke, and the Gospel of John. These are books of New Testament canon. This set of books 


\section{Terminological Names Of the Deity in the Scriptures}

Hebrew Bible starts with the term "ẹlohtim"11 as the name of their deity whose exclusive worship is demanded. ${ }^{12}$ Elohim in form is plural form of $E l$ or Elohe, meaning; might, power, great prince (nəśî̀' 'élōhîm), ${ }^{13}$ great wrestlings (nafatûlê 'ělōhîm), ${ }^{14}$ high hills (har-'élōhîm), ${ }^{15}$ etc. Elohim has been used for other deities (elohim aherim) as well. ${ }^{16}$ Elōôe, Eloah, 'élōha, 'ělōhha and 'ělwōhha are other shorter forms of elohim. ${ }^{17}$ Deity in the dialogue with Moses uses His name as "ělōhe." 18 God's name turns to be combined as in the form of "yəhwâ 'élohîm,"19 the most common generic word for deity, even though sometimes returning to the single usage of both terms as "élohîm" and as "yəhwâa." "2122 Elohim refers to God of Israel and is

are considered to be authoritative NT scripture. The first three Gospels are commonly classified as the Synoptic Gospels. The rest of the Christian books are called epistles addressed to a recipient or recipients, perhaps part of exchanged correspondence which most of them have been written by Paul.

1

The Qur'ān, literally "the recitation" is the scriptural text of Islam. Muslims consider the text in its original Arabic to be the literal word of Allah, revealed to Muhammad over a period of twenty-three years and view the Qur'an as God's final revelation to humanity. Muslims regard the Qur'ān as the culmination of a series of divine messages that started with those revealed to Adam who regarded as the first prophet, and was given by God the Suhuf-i-Ibrahim (Scrolls of Abraham). Qur'an affirms the Tawrat (Torah), the Zabur (Psalms), and the Injil (Gospel). The Qur'anic text assumes familiarity with many events from Jewish and Christian scriptures, retelling some of these historical events in distinctive ways, and referring obliquely to others. It rarely offers detailed accounts of historical events. Islamic dispensations is due to the common divine source, and that the Christian or Jewish texts were authentic divine revelations given to prophets. However those texts were neglected, corrupted (tahrif) or altered in time by the Jews and Christians and have been replaced by God's final and perfect revelation, which is the Qur'ān. However, many Jews and Christians believe that the historical biblical archaeological record refutes this assertion, because the Dead Sea Scrolls (the Tanakh and other Jewish writings which predate the origin of the Qur'an) have been fully translated, validating the authenticity of the Greek Septuagint. See Bernard Lewis, The Jews of Islam,(Princeton University Press, 1984); The Dead Sea Scrolls Bible, the oldest known Bible translated for the first time into English (HarperSanFrancisco, 2002); Leaman, Oliver, "Cyberspace and the Qur'an," in Leaman Oliver, The Qur'an: an encyclopedia (Great Britain: Routeledge, 2006), pp. 130-135.

${ }^{11}$ The term elohim appears some 2.600 times in the Hebrew Scripture. If Elohim be regarded as derived from $E 1$, its original meaning would be "the strong one." According to Wellhausen derivation of El, from ul (Skizzen, III, 169); or "the foremost one", according to Nöldeke's derivation of $E l$ from $u l$ or $\mathrm{il}$, "to be in front" (Sitzungsberichte der berlinischen Akademie der Wissenschaften, 1880, pp. 760 sqq.; 1882, pp. 1175 sqq.); or "the mighty one," according to Dillmann's derivation of El from alah or alay, "to be mighty" (On Genesis, I/1). See Catholic Encyclopedia art. "Elohim."

12 This can be seen in the first book Genesis Chapter 1 verse 2.

13 Genesis 23/6.

14 Genesis 30/8.

15 Psalms 68/16.

${ }^{16}$ Exodus 20/3, Deuteronomy 5/7.

17 Genesis 24/3, Deut. 32/15-17, Daniel 11/38

18 Exodus 3/6.

${ }^{19}$ Genesis 2/4.

${ }^{20}$ Genesis 6/4. 
thus synonimous with or interchangeable with Yahwa. The HB's deity uses the term $Y_{a h w a a^{23}}$ as His name ('ănî yəhwâa). ${ }^{24}$ The deity's name appeared to Moses $^{25}$ out of the midst of the thorn-bush ${ }^{26}$ is yəhwa.$^{27}$ For the first time elohim diverts from the composers of Tanakh ${ }^{28}$ regarding His name: "And 'élōhîm said moreover to Moses: Thus shalt thou say unto the children of Israel ('el-banê yiśsarā'ell): yahwâ the'ělōhê of your fathers, the 'ělōhê of Abraham, the 'élōhê of Isaac, and the 'élōhê of Jacob, hath sent me unto you. This is my name for ever, and this is my memorial unto all generations." 29

Another important scriptural designation and the root and singular noun form word of elohim is " $e l^{30}$ also means; mighty, strong and prominent, and

${ }^{21}$ We used a transliteration of the Tanakh into Hebrew. Therefore the word "elohim" and "yəhwâ" are written in vowels. The original Tanakh is written consonantally as ELHM and YHWH. This tetragrammaton mentioned more than 6.600 times in the Tanakh, also occurs on the Moabite Stone (ninth century BC). S. David Sperling, The Encyclopedia of Religion, V. 6/1. In the $7^{\text {th }}$ century A.D. when a complete system of vowel signs was added to the mainly consonantal text of Hebrew Bible, the vowel signs for the words disappeared. R.T.A. Murphy, New Catholic Encyclopedia, V. VIII/989.

22 Genesis 6/3.

23 The proper name of the God whose exclusive worship is demanded by the authors of the Hebrew Scriptures written consonantly as $Y H V H$. It is transliterated as "Jehovah" and translated as "lord (adonai)", and "host". See Deotoronomy 17/1-3. The original meaning of the name $Y H W H$ is unknown to modern scholars. Only one Biblical writer, the author of Exodus 3/14, attempted an explanation, by relating the name to the verb "hayah" (be, exist). According to genesis 4, Eve knew God by the name of Yahwa.

${ }^{24}$ Exodus 6/2.

${ }^{25}$ The record in the Hebrew Bible about the father and mother of Moses is: "And Amram took Jochebed his aunt as wife; and she bore him Aaron and Moses. And the years of the life of Amram were a hundred and thirty-seven years." Exodus 6/20.

${ }^{26}$ The burning bush is a miracle performed by God (YHWH) on Mount Horeb to inform Moses of his divine calling. God appeared to Moses from a bush which was aflame, but which was not consumed by the fire. Exodus 3/2.God's spirit, in the bush, then declared "I am your father's God, the God of Abraham, the God of Isaac, and the God of Jacob." Exodus 3/6.

${ }^{27}$ Exodus 3/4.

${ }^{28}$ Tenakh or Tenak) is an acronym that identifies the Hebrew Bible. The acronym is formed from the initial Hebrew letters of the Tanakh's three traditional subdivisions: 1- Torah, meaning "teaching" or "law," includes the Five Books of Moses. The Torah is also known by its Greek name, "the Pentateuch," which similarly means "five scrolls." 2- Nevi'im, meaning "Prophets." This division includes the books which, as a whole, cover the chronological era from the entrance of the Israelites into the Land until the Babylonian captivity of Judah (the period of prophecy). However, they exclude Chronicles, which covers the same period. The Nevi'im are often divided into the Earlier Prophets, which are generally historical, and the Later Prophets, which contain more exhortational prophecies. 3Ketuvim, meaning "Writings," are sometimes also known by the Greek title "Hagiographa." These encompass all the remaining books, and include the Five Scrolls. See Astrow Dictionary, p.1409; Ben Yehudah Dictionary, vol.12 pp.6138-6139.

${ }^{29}$ Exodus 3/15. God becomes God of Israel by Moses (Yəhwâ 'ělōhê yiśarā'ēel). Exodus 5/1, 32/27.

${ }^{30}$ El was originally a Canaanite god whose name, meaning powerful one, became generic for all $\operatorname{god}(\mathrm{s})$ and mighty men in Hebrew. It also is used in reference to deities of other religions, to angels, and to human judges.Unlike elohim, el has clear antecedents in older Semitic languages. Early documents 
its function corresponds generally to that of elohim. El can substitute for yahwa as a proper name for the deity of Israel and is thus synonymous with or interchangeable with 'el-yzhwa. . $^{31}$ The Hebrew word "el" can take definite article and appear as ha el "the deity." 32 It can also refers to pagan deities in the form of "'e $\bar{l} z \bar{a} r$ " (strange god). ${ }^{33}$ Another name the Hebrew Bible used for ther deity is "'ehayeh 'ăšer 'ehayeh" I AM THAT I AM. ${ }^{34}$

The Hebrew Bible uses the term lord ( $\breve{a} d \bar{o} n)^{35}$ as a name for deity in two distinct usages, namely, as an honorific title for deity, and as a substitute for deity's sacred proper name Yahwa. As a divine epithet it expressed the sovereign power and dominion of deity and to mean the ultimate Lord Yahwa ('ādōn yahwâ), ${ }^{36}$ Lord of all the earth, ${ }^{37}$ and Lord of lords (ădōnê hā'ădonnîm). ${ }^{38} \hat{A} d \bar{o} n$ was preferred to $\mathrm{Ba}^{\prime} \mathrm{al}^{39}$ to express Yahwa's lordship since the latter was used as the proper name of many Canaanite gods. ${ }^{40}$ In the period of the writing the Scripture, the title adon was frequently linked to the holy name of Yahwa, as it is in "The Lord Yahwa ( $\bar{a} d w \bar{o} n$ yəhwâ) and the Lord Yahwa of hosts (ădōnāy yahwih sabā'wōt). ${ }^{41}$ The Prophets thereby emphasized Yahwa's supreme authority and the subjection of Israel to Deity

shows that the word El was found in Proto-Sinaitic, Phoenician, Aramaic, and Hittite, Amorites texts, and at the top of a list of gods as the Ancient of Gods or the Father of all Gods, in the ruins of the Royal Library of the Ebla civilization, in the archaeological site of Tell Mardikh in Syria dated to 2300 BC. See Frank Moore Cross, Canaanite Myth and Hebrew Epic. (Cambridge, Harvard University Press, 1973); Franz Rosenthal, "The Amulet from Arslan Tash", trans. in Ancient Near Eastern Texts, 3rd ed. with Supplement, (Princeton: Princeton University Press, 1969), p. 658; S. David Sperling., The Encyclopedia of Religion (New York-London, 1986), V: 6/1-2; James TeixidorThe Pagan God (Princeton: Princeton University Press, 1977). El is linguistically equivalent to the Moslem "Allah".

31 El's most common usage is in Numbers 12/13, "How shall I curse God "mâ 'eqqōb lō' qabōh 'êl ûmâ," Numbers 23/8, "God is not a man (ēl wîkazzēb ûben-'ādām)." Numbers 23/19.

32 "And He said, I am God, the God of thy father (ānōkî hā'ēl 'ělōhê 'ābîkā)," Genesis 46/3.

33 Psalms 44/21, and "There shall no strange god be in thee; neither shalt thou worship any strange god

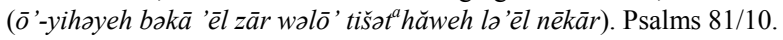

34 "When Moses was sent to Pharaoh, Moses asked God that the people will ask Your name, what shall I say? ělōhîm said: "I AM THAT I AM ('ehəyeh 'ăšer 'ehəyeh). Thus shalt thou say unto the children of Israel: I AM ('ehəyeh) hath sent me unto you." Exodus 3/14.

35 The term adon, signifying lord or master, is often used of persons having some kind of superiority, e.g. a husband, as Sarah said for her husband "my lord being old ('edənâ wa'dōn̂̀ zāqēn)" Genesis 18/12, a king, 1 Samuel 24/11, and a tribal patriarch Genesis 24/10. Adonai used for Abraham as well. Genesis $24 / 12$.

${ }^{36}$ Exodus 23/17, 34/23; Isaiah 1/24; Psalms 113, 114.

37 Joshua $3 / 11,13$.

38 Deut 10/17, Psalm 136/3.

39 Ba'al is a Northwest Semitic title and honorific meaning "master" or "lord" that is used for various gods who were patrons of cities in the Levant, cognate to Assyrian Bèlu. Article "Baal" by W. Robertson Smith and George F. Moore in Encyclopcedia Biblica, edt T. K. Cheyne-J. Sutherland Black (MacMillan: London, 1899).

40 R.T.A. Murphy, New Catholic Encyclopedia, v. VIII/988.

${ }^{41}$ Isaiah 3/15. 
as His servant. ${ }^{42}$ Adon was substituted in the plural form with the first person singular possessive suffix, meaning literally "my Lord" as it is in "ădōnāy yěhwih. $"{ }^{43}$ This is because Yahweh was treated with growing reverence and respect.

The New Testament enunciates no new name of deity. ${ }^{44}$ In NT God is called by names that convey the meaning of sovereignty. It names the God as "kurios (the Lord). Kurios seems a title-name for God; such as the "Lord of Heaven and earth" and "the Lord of lords," "the Lord of the harvest." 45 This word denotes the lord as owner and master in the spheres of family and public life. ${ }^{46}$ The term is usually used over against the word doulos "slave." ${ }^{47}$ The relationshiip between God and humans is the one between a lord and a slave. ${ }^{48}$ The "Lord" either with definite article or without used for $\operatorname{God}^{49}$ in substitution for Hebrew Yahwa. ${ }^{50}$

Another most common name for God in NT is Father $(A b b a)$. Jesus Himself called the God as "Father:" 51 Jesus used $E l$, the Hebrew name for God: "And about the ninth hour Jesus cried with a loud voice, saying, Eli, Eli! Lama sabachthani? that is to say, My God, my God! Why hast thou

\footnotetext{
42 Murphy, passim.

43 As appears in Genesis 15/2.

${ }^{44}$ Within Christianity God is known by names that describe his character. (i.e El-Roi [God who sees], Jehovah (Yahweh)-Nissi [The Lord is my banner], Jehovah (Yahweh)-Jireh [The Lord will provide], et al.

45 Luke 10/2.

${ }^{46}$ Greek Kurios (Lord) found some 600 times in the NT.

${ }^{47}$ Colin Brown, ed., New International Dictionary of New Testament Theology (Grand Rapids: Zondervan, 1978), s.v. "Lord, Master," by H. Bietenhard; A.W. Pink, The Sovereignty of God (Grand Rapids: Baker, 1982), 19. Webster's New World College Dictionary,4th ed., s.v. "free will." See also Dagobert D. Runes, ed. Dictionary of Philosophy (New York: Philosophical Library, 1983), s.v. "Freewill," by Ledger Wood.

48 "His lord said unto him, Well done, good and faithful servant; thou hast been faithful over a few things, I will make thee ruler over many things: enter thou into the joy of thy lord." Mat 25/23; "In that hour Jesus rejoiced in spirit, and said, I thank thee, O Father, Lord of heaven and earth." Luke 10/21.

49 "Howbeit Jesus suffered him not, but saith unto him, Go home to thy friends, and tell them how great things the Lord hath done for thee, and hath had compassion on thee." Mark 5/19. Gospel of Mark written in $70 \mathrm{AD}$

50 "Jesus said unto him, It is written again, Thou shalt not tempt the Lord thy God." Matthew 4/7. This verse was cited from the Tanakh Deut. 6/16 "Ye shall not tempt the Lord your God, as ye tempted him in Massah."

51 Mat 6/1, 4. "And when ye stand praying, forgive, if ye have ought against any: that your Father also which is in heaven may forgive you your trespasses." Mark 11/25. "All things are delivered to me of my Father." Luke 10/22. Jesus's call to God as Father (Abba) is not a new doctrine to Nt since Hebrew Bible entitled God as Father. "Doubtless thou art our father ('ābînu), though Abraham be ignorant of us, and Israel acknowledge us not: thou, $\mathrm{O}$ yəhwâ) art our father, our redeemer; thy name is from everlasting." Isaiah 63/16; Genesis 50/17.
} 
forsaken me?" 52 Other terms used to mean God are "despotes," 53 theos (yeos) "God", ${ }^{54}$ I AM, ${ }^{55}$ theotes (Godhead) ${ }^{56}$ These names more frequently applied in a specific way to Jesus Christ. The usage of "Master, Lord" for Jesus ${ }^{57}$ Christ ${ }^{58}$ is conspicous in Mark, ${ }^{59}$ Matthew, ${ }^{60}$ Luke $^{61}$ and John. "That the Son of man is Lord." "62 Jesus Christ himself wanted to be called as Lord: "Ye call me Master and Lord: and ye say well; for so I am." ${ }^{63}$ Another term used for Jesus is Rabbi means Master and my Master. ${ }^{64}$

All the Qur'anic affirmations relating to the existence of deity refer to Allah. ${ }^{65}$ It refers to the proper name of deity without any other beside Him. Allah is the contraction of the word al-ilah as the derivative of HebrewAramaic $E l,{ }^{66}$ which appaears in pre-Islamic Arabic poetry to convey a sense

52 Matthew 27/46; Mark 15/34. Hebrew eli means "my God", an exclamation used by Christ on the cross. Mark as usual, gives the original Aramaic form of the word, Eloi.

53 times: Lu. 2/29; Acts 4/24; 2 Pet. 2/1; Jude 4; Rev. 6/10.This is from which we get the word "despot."

54 This is equivalent to the Hebrew Elohim, 1,000 times mentioned in the NT. In the NT all the persons of the trinity are called "God" at one time or another.

55 "Before Abraham was, I AM," John 8/58.

${ }^{56}$ Col. 2/9; Rom. 1/20.

57 Jesus derived from the Hebrew "'”shua" (Y'shua) or "Je-Hoshua" meaning Jehovah is salvation.

58 Christ is equivalent to the Hebrew 'Messiah' (Meshiach), "The Anointed One."

59 "So then after the Lord had spoken unto them, he was received up into heaven, and sat on the right hand of God." Mark 16/19-20, 12/32. Mark is the oldest gospel. Matthew and Luke are believed to come later, and draw on Mark. Gospel of Matthew and Gospel of Luke have been written during the 80-90 AD.

60 "At that time Jesus answered and said, I thank thee, O Father, Lord of heaven and earth, because thou hast hid these things from the wise and prudent, and hast revealed them unto babes." Matthew 11/25.

61 "In that hour Jesus rejoiced in spirit, and said, I thank thee, O Father, Lord of heaven and earth, that thou hast hid these things from the wise and prudent, and hast revealed them unto babes: even so, Father; for so it seemed good in thy sigt." Luke 10/21; "When Simon Peter saw it, he fell down at Jesus' knees, saying, Depart from me; for I am a sinful man, O Lord.” Luke 5/8.

62 Luke 6/5.

63 John $13 / 13$.

64 "Then Jesus turned, and saw them following, and saith unto them, What seek ye? They said unto him, Rabbi, (which is to say, being interpreted, Master,) where dwellest thou?.” John 1/38; Mat 23/7-8; Mar $9 / 5$; Joh $3 / 26,1 / 38,49,3 / 2,6 / 25$, etc.

${ }^{65}$ A well established Islamic tradition enumerates 99 Names of God, which they in fact are not His names but His functional and personal attributes. Therefore Allah and Rabb has not been enumarated amongst them. The word Allah appears about twenty seven hundred times in the text of the Qur'an. As Allah contains the Arabic definite article "al", "Allah" means "the God." Examples of the usage of rabb in the Qur'an: Say: "Who is the Lord of the heavens and the earth? Say: "Allah."” 13/16. "Allah, your Lord and the Lord of your fathers of old." 37/126. Allah is the Lord-Master of the worlds, 1/1 Allah, the Master of the worlds is to be feared, 5/28. to the Master of the worlds must be submitted, $6 / 71 ; 40 / 66$. to be praised, $40 / 65$.

${ }^{66}$ Allah is the derivative of Hebrew El and Elah. Elah is Aramaic "god." Elah or Elleh appears in the Hebrew Bible in Jer. 10/11: "Thus shall ye say unto them, the gods that have not made the heavens and 
of the "divinity," and was used to refer to a deity worshipped in Mecca. ${ }^{67}$ The term "Rabb" as a second name of God is used for about a thousand times, most frequently after Allah. The term rabb means; lord, and master of a slave. ${ }^{68}$ In many verses $r a b b$ is used in the place of Allah by taking over His functions. ${ }^{69}$ The term rabb has also been used for normal humanbeing and it was in use in for humans as well before the advent of the Qur'an. ${ }^{70}$

\section{Oneness-Unicity of the Deity}

The Biblical writers and modern scholars disagree about the period in which the explicit monotheism and monolatry formed in Judaism. ${ }^{71}$ Because even Bible mentions time and time again that Israelites practiced Henotheism; worshipping other deities alongside with Yahwa. ${ }^{72}$ But the books of the Bible agree that Israel's tenure in its own land depended on the exclusive worship of Yahwa. Hence the exclusive worship of Yahwa, was the religious expression of the political and social factors that brought Israel into existence.

Nonetheless, before unicity, Yahwa had to prove His divinity and superiority over other deities. All Biblical writers agreed that $\mathrm{He}$ was superior to other deities. He to proclame His superiority over other deities, says: "For I will pass through the land of Egypt this night, and will smite all the firstborn in the land of Egypt, both man and beast; and against all the gods of Egypt I will execute judgment: I am Yahwa ('ănî yəhwâ)." ${ }^{, 73} \mathrm{He}$ is

the earth, even they shall perish from the earth, and from under these heavens (šzmayyā' 'èlleh)." As Allah contains the Arabic definite article "al", "Allah" means "the God.

67 The origin of al-ilah is found in a root common to various ancient Semitic languages, el from which are derived the names of the divinities encountered in ancient Semitic cults. It appears likely that in the Pantheon of the old Meccan religion. Louis Gardet, The Encyclopedia of Religion, 6/27. Prophet Muhammad, in pre-Islamic times, found the Meccans believing in a supreme God whom they called Allah, thus already contracted. With Allah, however, they associated other minor deities, some evidently tribal, others called daughters of Allah. Qur'an's reform was to assert the solitary existence of Allah. The first article of the Muslim creed, therefore, "Lailahe illa-llah" means only, as addressed by It to the Meccans, "'There exists no God except the one whom you already call Allah." Naturally, this precise historical origin is not clear to the Muslin exegetes and theologians. But that Allah is a proper name, applicable only to their peculiar God.

68 Pre-Islamic Arabia probably applied this term of $r a b b$ to its gods. In this sense the word corresponds to the term like Hebrew Ba'al, Adonis etc.in the Northwestern Semitic languages, where $r a b b$ means "much great". A.J. Wensinck, The Encyclopaedia of Islam, $2^{\text {nd }}$ ed.VIII/350; For the etymology and meaning of the term rabb see A. Jeffery, The Foreign Vocabulary of The Qur'an (Baroda, 1938), 136.

${ }^{69}$ Qur'an 2/126; 2/260; 3/41; 9/129.etc.

${ }^{70}$ Qur'an $12 / 39 ; 3 / 64 ; 3 / 80 ; 9 / 31$ etc.

${ }^{71}$ It took centuries for the Israelites to become monolaterous and monotheistic.

72 Henoism is to mean devotion to a single "God" while accepting the existence of other gods. Henotheism is closely related to the theistic concept of Monolatry, which is also the worship of one God among many.

73 Exodus 12/12. 
now the only divinity in control of earthly and heavenly events. ${ }^{74}$ So Yahwa must be the one God. Isaiah ${ }^{75}$ was the most consistent monotheist, insisting that Yahwa was the sole god in existence. ${ }^{76}$ Deuteronomy clearly proclaims that: "Hear Israel: Yahwa our God is one Yahwa." 77

In the NT God or Lord is one. ${ }^{78}$ Jesus himself to teach the oneness of God says: "And Jesus said unto him, Why callest thou me good? There is none good but one, that is, God," "A9 "And Jesus answering saith unto them, have faith in God." ${ }^{80}$ The Holy Trinity is a term used to denote God in almost all Christianity. It means God is the One in Three Persons; Father (God) Son (Jesus Christ), Holy Ghost-Holy Spirit. "Go ye therefore, and teach all nations, baptizing them in the name of the Father, and of the Son, and of the Holy Ghost."

According to the Qur'an Allah is unique and One, ${ }^{82}$ whose prerogatives over mortals cannot be shared. The unshared godship belongs to the true Deity. No other divinities are associated with Allah, and no divine intermediaries lie between Him and man. The only unpardonable sin being the association of deities with Allah (shirk) ${ }^{83}$ It is also clearly stated the the unique (wâhid) Allah is one (ahad) in Himself. This is divine unicity. Tawhid $^{84}$ used to describe the external and internal unicity of Deity; Allah

\footnotetext{
${ }^{74}$ Yahveh proves His uniqueness amongst other gods by being successful in bringing the Isrealites out of Egypt: "Now I know that Jehovah is greater than all gods; for in the thing in which they acted haughtily [he was] above them." Exodus 18/11. And now He deserves burnt-offerings: "And Jethro, Moses' father-in-law, took a burnt-offering and sacrifices for God; and Aaron came, and all the elders of Israel, to eat bread with Moses' father-in-law in the presence of God.” Exodus 18/12. God decides His oneness in the third months after bringing the Israelites out of Egypt by saying to Moses at Sinai on the top of the mountain saying: "Thou shalt have no other gods before me. Thou shalt not bow down thyself to them, nor serve them; for I, Jehovah thy God, am a jealous God" Exodus 20/3-5. God said to Moses: "Ye shall not make beside me gods of silver, and ye shall not make to you gods of gold." Exodus 20/23.

75 Isaiah is a collection of prophecies from a 300-year period attributed to Isaiah, who may have been a Biblical priest. He received his call to prophesy in the year of King Uzziah's death (c.742 BC).

76 Isaiah 43/10-12, 44/6-8, 45/5-7 etc.

77 Deut 6/4

78 "And call no man your father upon the earth: for one is your Father, which is in heaven." Matt 23/9. "Neither be ye called masters: for one is your Master, even Christ." Mat 23/10. "And the scribe said unto him, Well, Master, thou hast said the truth: for there is one God; and there is none other but he." Mark 12/32.

${ }^{79}$ Mark 10/18.

${ }^{80}$ Mark 11/22.

${ }^{81}$ Mat 28/19.

${ }^{82}$ Qur'an 41/6, 20/24; Chapter 112.

83 Qur'an 3/67.

${ }^{84}$ The word Tawhid, is non-Qur'anic, it appears in the Hadith inextricably integrated with the formulation of Muslim faith. When the religious sciences developed in Islam, the particular discipline of "ilm al-kalâm ("the science of the word" of God, or about God) was also called "ilm al-tawhîd ("the science of divine unicity").
} 
wahid ${ }^{85}$ and ahad.$^{86}$ Hence the Qur'an denounces with particular a triad of female divinities known throughout pre-Islamic Arabia; al-Lât (the Goddess), al-Uzzâ (the All-Powerful), and Manât (the one who presides over destiny and death), the so called daughters of Allah are ridiculed. ${ }^{87}$ Qur'an refutes the NT, which asserts that God have a Son; Jesus Christ, ${ }^{88}$ and reacted against Trinity as a betrayel of the divine unicity, and it was perceived a "cleft" in God.

\section{Description and Attributes of the Deity}

Although according to Hebrew Bible, in reality Yahwa's true nature cannot be known, but straits regarding the characteristic essence and attributes of Him appears in It. ${ }^{89}$ Because Yahwa is known by His attributes, and is so described in the Scripture. As the Israelites becoming monolaterous and monotheistic, the figure of Yahwa began to absorb many of the functions and attributes of the older gods. After having obtained the god El's name, in addition, He attained his "beneficence," "wisdom" and likewise, Baal's thunderous voice. ${ }^{90}$

According to Hebrew Scripture Yahwa is usually described in terms of attributes that are related to humans; first of all, they personify Yahwa with masculine traits, ${ }^{91}$ provider, lawgiver-king, ${ }^{92}$ most High, $^{93}$ Majesty, ${ }^{94}$

85 Qur'an 5/73.

86 Qur'an 112/1.

87 Qur'an 16/57-59.

88 Qur'an 4/171.

${ }^{89}$ Because the Hebrew Bible is not a systematic theological treatise and because not all internal contradictions were removed by its editors, we find major disagreements among the writers about the crucial elements of Israelite faith of concepts of God. S. David Sperling, The Encyclopedia of Religion, artcl. "God", 6/1. The distinction between essence and attributes of God did not surface in Judaism until the more philosophically oriented Middle Ages. Louis Jacob, New Catholic Encyclopedia, artcl. "Attributes of God".

90 "The adversaries of the Yahveh shall be broken to pieces; out of heaven shall he thunder upon them: the Yahveh shall judge the ends of the earth; and he shall give strength unto his king, and exalt the horn of his anointed." I Samuel 2/10. Baal is a Northwest Semitic honorific title meaning "master" or "lord" that is used for various gods who were patrons of cities in the Levant, cognate to Assyrian Bēlu. It is used as a substitute for Hadad, a god of the rain, thunder, fertility and agriculture, and the lord of Heaven. Hadad was a very important northwest Semitic storm and rain god. Hadad was the son of $E l$, who had once been the primary god of the Canaanite pantheon, and whose name was also used interchangeably with that of the Hebrew God, Yahweh.See Catholic Encyclopedia, artcls "El", "Hadad," and "Baal."

91 This, might be, due to exclude the female divinities. However the Biblical writers did not tolerate Yahveh's absorbtion of the attributes of Near Estearn goddesses. They, furthermore, condemned the widespread royal and popular worship of female deities. It is notworthy, as a historical reality, that the Northern Kingdom of Israel never had a reigning queen. In Israelites, there were some women prophets, but nofemale priests. See S. David Sperling, The Encyclopedia of Religion, 6/5. 


\begin{abstract}
Almighty (Shaddai),${ }^{95}$ Supreme Lord (Adonai),${ }^{96}$ Judge, ${ }^{97}$ His knowledge is unlimited, Righteous (sadāqâa). ${ }^{98}$ Holy $(q \bar{a} d \partial s ̌ w o \bar{c}) .{ }^{99}$ Gracious ${ }^{100}$ Good, ${ }^{101}$ Merciful, ${ }^{102}$ He does justice, ${ }^{103}$ punishes,${ }^{104}$ rewards, ${ }^{105}$ Redeemer, ${ }^{106}$ gets angry, ${ }^{107}$ jealous, ${ }^{108}$ repents, ${ }^{109}$ glorifies Himself, ${ }^{110}$ smites, ${ }^{111}$ Savior, ${ }^{112}$
\end{abstract}

92 Psa. 5/2, 29/10, 44/4, 47/6-8, 48/2, 68/24, 74/12, 95/3, 97/1, 99/4, 146/10; Isa. 5/1, 5, 41/21, 43/15, $44 / 6 ; 52 / 7$.

93 "I will praise Jehovah according to his righteousness, and will sing forth the name of Jehovah the Most High (yəhwâ 'elaywōn)." Psalm 7/17-18.

94 "Jehovah our Lord, how excellent is thy name in all the earth! who hast set thy majesty (hwōdəkā) above the heavens." Psalm $8 / 1$.

95 Many verses in the Old Testament do assert God's omnipotence without actually using the word itself. There are several times in the Bible when Yahveh is called simply "Almighty", and even Yahveh Himself attributes Himself Yahveh describes Himself first time as Almighty. Yahveh said to Jaqob: I am the Almighty (wayyō'mer lwō 'élōhîm 'ănî 'él šaday). Genesis 35/11, showing that the Bible supports the belief in an omnipotent God. Some such verses are: Psalms 33:8-9; Genesis 17:1; Jeremiah 32:27.

96 Adonai mentioned more than 300 times in the Hebrew Bible. Gen. 15/2. Ex. 4/10; Judges 6/15; 2 Sam. 7/18-20; Ps. 8, 114/7, 135/5, 141/8, 109/21-28.

97 Gen. $18 / 25$

98 "For righteous is Yahwa; He loveth righteousness, his countenance doth behold the upright." Psalm 11/7; Exodus 9/27.

99 "I Yahwa your God am holy." Leviticus 19/2. "For I am Yahwa who brought you up out of the land of Egypt, to be your God: ye shall therefore be holy, for I am holy." Leviticus 11/45. Yahwa frequently remindes His favor to Israelites, by bringing them out of Egypt, and hence deserves to be holy. The attribute "qadosh" used for divinities in Ugaritic and Phoenician, usually translated as "holy."

100 Moses siad to Yahwa: "And now, if indeed I have found grace in thine eyes, make me now to know thy way, that I may know thee, that I may find grace in thine eyes; and consider that this nation is thy people." Ex 33/13.

101 Psalm 100/5

102 "And Yahwa passed by before his face, and proclaimed, Yahwa God merciful (rakhûm) and gracious, slow to anger, and abundant in goodness and truth." Exodus 34/6.

103 Genesis 30/6.

104 "And Yahwa smote the people, because they made the calf, which Aaron had made." Exodus 32/35.

105 Saving the nations, as did for Noah. Multiplying the human-seed of whom He is pleased, as did for Abraham (Abram). Genesis 13/16, 22/17.

106 Job 19:25

107 "And Yahwa said to Moses, I see this people, and behold, it is a stiff-necked people. And now let me alone, that my anger may burn against them, and I may consume them; and I will make of thee a great nation." Exodus 32/9-10. "And Aaron said, Let not the anger of my Lord burn! Tthou knowest the people, that they are [set] on mischief." Exodus 32/22.

108 Ex. 20/5, 34/14; Isa. 9/7; Zech. 1:14, 8/2. "For I, Yahwa thy God, am a jealous God." Deut.5 /9. Yahwa is frequently referred as a jealous god. This is borrowed from Babylonian text, where the goddess Sarpanitum is described by the identical term.

109 Genesis 6/5-6; "And Yahwa repented of the evil that he had said he would do to his people." Exodus 32/14.

110 Glorifies Himself in Pharaoh and in all his host etc.. Exodus 14/17.

111 Deut $7 / 2$. 
Refuge, ${ }^{113}$ Father ('âbinû). ${ }^{114}$ The Self-Existent One. ${ }^{115}$ The First and the Last, ${ }^{116}$ Everlasting. ${ }^{117}$

All the names and attributes are to prove and to persuade the people that Yahwa can do whatever He wants. The omnipotence of Yahwa is the prevailing doctrine of $\mathrm{HB}$, as it indeed must be in any monotheistic religion. Thus He has the power to do what He desires within His universal state. All the peoples of the earth are regarded as nothing. Daniel wrote: "He does as He pleases with the powers of heaven and the peoples of the earth. No one can hold back his hand or say to Him: "What have you done?"118 Yahwa has the will to do what He desires. He does what He says He will do. ${ }^{119} \mathrm{He}$ has the knowledge required to rule over all. He knows what is going on, and exactly what needs to be done. He knows the past, present, and future perfectly. He is omniscient. ${ }^{120}$

The HB prohibites imagery and the physical depictions of all divine images, ${ }^{121}$ but stil Yahwa is often described humanlike ${ }^{122}$ with a face, ${ }^{123}$ a back, ${ }^{124}$ having arms, ${ }^{125}$ a powerful hand, ${ }^{126}$ and fingers, ${ }^{127}$ and legs. ${ }^{128} \mathrm{He}$ is a

112 Isa $43 / 3$.

113 "And Yahwa will be a refuge to the oppressed one, a refuge in times of distress." Psalm 9/9, 10/1.

1142 Sam. 7/14-15; Psa. 68/5; Isa. 63/16, 64/8; 1 Chron. 29/10. Yahwa said: I will be his father, and he shall be my son." $1 \mathrm{Chr} 17 / 14$.

115 Ex.chp. 3.

116 Isa. $44 / 6,48 / 12$.

117 Gen. 21/33; Psa. 90/1-3, 93/2; Isa. 26/4.

118 Daniel 4:35

119 Isaiah. 46/9, 10; 55/11.

120 Genesis 22/11, 3/4; Psa 139/4, 5, 11 .

121 Exodus 20/4, 34/17; Deuteronomy 4/15-17, 5/8; Isaiah 40/18. Exodus is the book of the Bible, 2d of the 5 books of the Law (the Pentateuch or Torah) ascribed by tradition to Moses. The book continues the story of the ancestors of Israel in Egypt. Deuteronomy book of the Bible, literally meaning "second law," last of the five books (the Pentateuch or Torah) ascribed by tradition to Moses. Deuteronomy purports to be the final words of Moses to the people of Israel on the eve of their crossing the Jordan.

122 Genesis $1 / 27,18 / 2$.

123 Exodus 33/20.

124 Exodus 33/ 23.

125 Deuteronomy 32/40.

126 Exodus 13/3. "And Israel saw the great power [with] which Jehovah had wrought against the Egyptians; and the people feared Jehovah, and believed in Jehovah, and in Moses his bondman." Exodus 14/31. "Thy right hand, Jehovah, is become glorious in power: Thy right hand, Jehovah, hath dashed in pieces the enemy." Exodus 15/6. He that hath blameless hands and a pure heart. Psalm 24/4.

127 "And He gave to Moses, when he had ended speaking with him on mount Sinai, the two tables of testimony, tables of stone, written with the finger of God." Exodus 31/18. "And the tables [were] God's work, and the writing was God's writing, engraven on the tables." Exodus 32/14.

128 Nahum 1/3, Zechariah 14/4. 
warrior; ${ }^{129} \mathrm{He}$ fights, ${ }^{130} \mathrm{He}$ speaks ${ }^{131} \mathrm{He}$ is a doctor, ${ }^{132}$ a Shepherd. ${ }^{133} \mathrm{He}$ is in the Heavens. ${ }^{134}$ Isaiah says that Yahwa is indescribable, but dresses Him in armor and a helmet. ${ }^{135}$ Deuteronomy justifies this prohibition by appeal to Israel's experience at Sinai, where they heard Yahwa but did not see Him. ${ }^{136}$ Hebrew images of Yahwa as such, borrowed from the figure of Baal, the thunder god. Images of gods in human and animal form are well known in Egyptian and Canaanite religion. ${ }^{137}$

The NT enunciates no new God and no new doctrine of God. The authors of the Gospels and Epistles whose Hebrew Bible was mainly the Greek Septuagint (LXX) continued to proclaim that the God and Father of Jesus Christ is the God of Abraham, Isaac, and Jacob, the God of earlier covenants. Jesus inherited the HB Jewish faith in Yahwa, which held that God was the creator of the world, ${ }^{138}$ who elected Israel as His people and gave them His law. ${ }^{139}$ God is the Highest ${ }^{140}$ Almighty (Pantokrator), ${ }^{141}$ Savior, ${ }^{142}$ Logos (Word). ${ }^{143}$ God speaks, ${ }^{144}$ judges. ${ }^{145}$ "Glory to God in the highest." ${ }^{146}$ For God all things are possible.,"147

129 Moses said: "Jehovah is a man of war; Jehovah, his name." Exodus 15/3. 15/3, Psalms 24/8.

130 Exodus 14/14

131 "And Jehovah said to Moses, Thus shalt thou say to the children of Israel: Ye have seen that I have spoken with you from the heavens." Exodus 20/22.

132 "I am Jehovah who healeth thee." Exodus 15/26.

133 David says: "Jehovah is my shepherd; I shall not want." Psalm 23/1.

"Jehovah looketh from the heavens; he beholdeth all the sons of men." Psalm 33/13.

135 "And He put on righteousness as a breastplate, and a helmet of salvation upon his head; and he put on garments of vengeance [for] clothing, and was clad with zeal as a cloak." Isaiah 59/17.

136 Deuteronomy $4 / 15 \mathrm{ff}$.

137 S. David Sperling, The Encyclopedia of Religion, V. 6/6.

138 "And as touching the dead, that they rise: have ye not read in the book of Moses, how in the bush God spake unto him, saying, I am the God of Abraham, and the God of Isaac, and the God of Jacob?" Mark 12/26. What the New Testament announces is that this God has acted anew in inaugurating God's final reign and covenant through the career and fate of Jesus of Nazareth. Reginald H. Fuller, The Encyclopedia of Religion, V. 6/8.

139 "And Jesus answered him, The first of all the commandments is, Hear, O Israel; The Lord our God is one Lord. And thou shalt love the Lord thy God with all thy heart, and with all thy soul, and with all thy mind, and with all thy strength: this is the first commandment." Mark 12/ 29-30.

140 "And the multitudes that went before, and that followed, cried, saying, Hosanna to the son of David: Blessed is he that cometh in the name of the Lord; Hosanna in the highest." Matthew 21/9.

141 "And will be a Father unto you, and ye shall be my sons and daughters, saith the Lord Almighty." 2 Cor. 6/18.

142 "And my spirit hath rejoiced in God my Saviour." Luke 1/47.

143 "In the beginning was the Word, and the Word was with God, and the Word was God." John 1/1 ff.

144 "And lo a voice from heaven, saying, This is my beloved Son, in whom I am well pleased." Matthew 3/17; Luke 5/20; Acts 8/29.

145 "And I seek not mine own glory: there is one that seeketh and judgeth." John $8 / 50$.

146 Luke 2/14. 
What the NT announces is that this God has acted anew in inaugurating God's final reign and covenant through the career and fate of Jesus of Nazareth. ${ }^{148}$ That is Lord God turns into Jesus Christ, and He became incarnate in Jesus Christ to accomplish the reconciliation of God and humanity. It is because the God of the Hebrew Bible Who is a God of wrath turns to be the God of the love through Christ.

Jesus is the Son of God. ${ }^{149}$ This is because Jesus had no father and Mary conceived of him by God's Spirit. It is said to Mary: "And the angel answered and said unto her, The Holy Ghost shall come upon thee, and the power of the Highest shall overshadow thee: therefore also that holy thing which shall be born of thee shall be called the Son of God."150 "And there came a voice from heaven, saying, "Thou art my beloved Son, in whom I am well pleased." ${ }^{151}$ Jesus himself declared himself as the Son of God: "He said, I am the Son of God." 152 "And then shall appear the sign of the Son of man in heaven: and then shall all the tribes of the earth mourn, and they shall see the Son of man coming in the clouds of heaven with power and great glory." 153 This position exulted Jesus to a position as close ass possible to God, to God's "right hand," consequently bestowed him receptance by the people.

Christ Himself affirmed His deity. He applied to Himself the "I AM". ${ }^{154}$ He claimed to be the Adonai (Lord) of the HB. ${ }^{155} \mathrm{He}$ asserted His identity with the Father. ${ }^{156} \mathrm{He}$ exercised the chief prerogative of God. ${ }^{157} \mathrm{He}$ asserted omnipresence, ${ }^{158}$ omniscience ${ }^{159}$ omnipotence, ${ }^{160}$ mastery over nature, and creative power. ${ }^{161} \mathrm{He}$ received and approved human worship. ${ }^{162}$ Jesus dares to affirm the will of God, as though he himself stood in God's place. Jesus's

S. David Sperling, passim, 6/8

"You are the Son of God." Mark 1/1, 3/11; Mat 27/40. Son of God, is originally a royal title. 
actions are God's actions. ${ }^{163}$ Hence Jesus's word and work are God's word and work; what God does, Christ does at the same time. ${ }^{164}$ God and Jesus Christ are intermingled or intertwined with each other, ${ }^{165}$ and become interchangeable with each other. However Christ does not replace God. He is God's agent in revealing God to human beings. ${ }^{166}$ All the titles of majesty declare that Christ is God's agent, not God's surrogate. ${ }^{167}$

The Qur'an enunciates no new God and no new doctrine of God. It continued to proclaim that Allah is the Rabb of Israelite Moses and Aaron, ${ }^{168}$ even the deity of Moses Yahwa was Allah, ${ }^{169}$ and described Allah as HB did. However every description of Allah is bound to fail ${ }^{170}$ yet the Qur'an ascribed a description or attributes to Him. All the Qur'anic attributes relating to Allah's transcendent perfections or His way of acting toward His creatures refer to Him as; the Creator, ${ }^{171}$ absolute Initiator, ${ }^{172}$ Most High, Most Great, ${ }^{173}$ Almighty, Avenger possessor of all sovereignty, ${ }^{174}$ Omniscient, ${ }^{175}$ Omnipotent, ${ }^{176}$ Possessor of all power, Supreme, ${ }^{177}$ allPowerful, Supreme Lord, King of the present and future life, ${ }^{178}$ Most Powerful, ${ }^{179}$ Glorious, ${ }^{180}$ Possessor of Majesty and Honor, ${ }^{181}$ Guide and Leader, ${ }^{182}$ Lord and Master of the believers, ${ }^{183} \mathrm{He}$ does whatever He wills, ${ }^{184}$

163 Ernest Fuchs, Studies of the Historical Jesus (Naperville, 1964), III/21.

164 "For the Father judgeth no man, but hath committed all judgment unto the Son." John 5/21;" can of mine own self do nothing: as I hear, I judge: and my judgment is just; because I seek not mine own will, but the will of the Father which hath sent me." John 5/30.

165 "Therefore, when he was gone out, Jesus said, Now is the Son of man glorified, and God is glorified in him. If God be glorified in him, God shall also glorify him in himself, and shall straightway glorify him.” Jon 13/31-2.

183 Qur'an 3/68. 
grants sovereignty to whomever He chooses. ${ }^{185}$ Inaccessible (al-azim) and cannot be compared to anything ${ }^{186}$ not questionable. ${ }^{187} \mathrm{He}$ is the Outermost and the Innermost, ${ }^{188}$ the total Truth ${ }^{189}$ and the Supreme and only Reality, Subsistent. ${ }^{190}$ The Provider, best Protector. ${ }^{191} \mathrm{He}$ is Compassionate towards the people, ${ }^{192}$ "Lord of majesty and generosity", ${ }^{193}$ Most Kind, Most Merciful, ${ }^{194}$ fearsome (al-Qahhar). ${ }^{195} \mathrm{He}$ is fully aware of all things, ${ }^{196}$ knows all, sees all, and hears all, ${ }^{197}$ and watchful. ${ }^{198}$ God is described as a filosopher and scholar: Knower of all secrets and declarations, $\mathrm{He}$ is the Most Wise, the Cognizant, ${ }^{199}$ with Him are the keys to all secrets; none knows them except He. ${ }^{200}$ His knowledge encompasses all things, ${ }^{201}$ none encompasses His knowledge, ${ }^{202}$ and so forth. Consequently, the few anthropomorphisms present in the Qur'an are: ${ }^{203} \mathrm{He}$ has eyes, ${ }^{204}$ arms, ${ }^{205}$ and face. ${ }^{206}$ But commandments ban all visual representation of God for use in worship.

\section{THE SOVEREIGNTY OF DEITY IN THE SCRIPTURES}

Sovereignty is a political term in its real meaning of the sense. It embraces the exclusive right to exercise supreme political that is; legislative, judicial, and executive authority over a geographic region, group of people, or

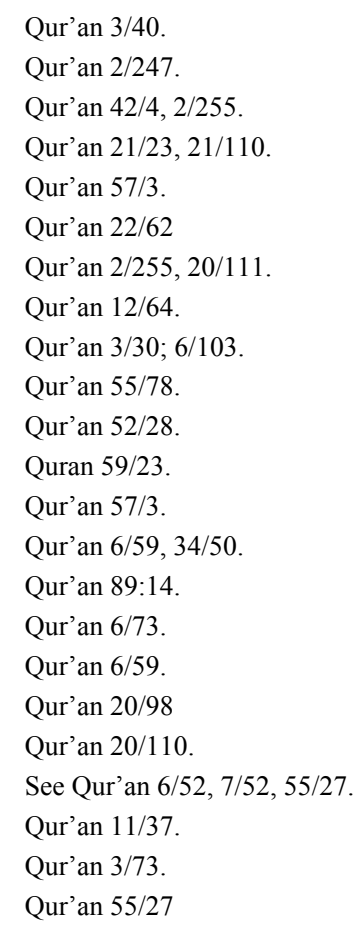


oneself. ${ }^{207}$ Sovereignty, even if not yet then, a formulated terminology and concept, has always been extant, especially as a divine sovereignty in all religions and polytheism, ${ }^{208}$ and particularly in the Semitic Scriptures. ${ }^{209}$

Our subject matter is the divine, that is God's sovereignty in the monotheistic three Scriptures. Every monotheistic religion and Scripture must affirm the divine sovereignty and declare that all political sovereignty, even secular, must ultimately belong and derive from God. According to them the divine sovereignty means not exaltation their gods only above other gods, but their complete power over nature and humankind.

\section{A. Sovereignty of the Deity}

The Hebrew words "malkuth or malekhet in Hebrew" and "malkutha in Aramaic is to be translated in political theology as "sovereignty and kingdom" and are used synonimously. Hebrew Malkuth means sovereignty, rule, reign, dominion kingship, kingly, and royalty, and in the later books of the HB mamlâkâ and mamlâkût signify primarily "royal domain, realm,

207 Jean Bodin (1530-1596) is considered to be the modern initiator of the concept of political sovereignty in secular meaning, stating sovereignty is absolute, thus indivisible. The political philosophers seems to have at least two distinct sovereignty; external and internal. External sovereignty is possessed by the political bodies in relation to other such bodies. This sovereignty implies the recognition of a state as having rights of jurisdiction over a particular people and territory. Internal sovereignty is possessed by political body in relation to a society that falls under its government. Sovereignty in this sense lies in supreme command over a civil society, and it has de jure (legal) aspect, as well as de facto (coercive) aspect. Legal sovereignty vests in that person, office or body whose decisions cannot legally be challenged in the court. Coercive sovereignty vests in that person, office or body which controls the powers exerted and enforced in the name of government. A. A. North, New Catholic Encyclopedia (Washington, 1981), V, XIII/487; Alfred E. Garvie, Encyclopedia of Religion and Ethics (New York, 1981), V, XI. In politics,sovereingty consists of authority and power. Authority (Latin auctoritas) used in Roman law as opposed to power (potestas and imperium) is often used interchangeably with the term "power". However, their meanings differ. "Power" refers to the ability to achieve certain ends, 'authority' refers to the legitimacy, justification and right to exercise that power. Political power (imperium in Latin) is a type of power held by a person or group in a society. Officially, political power is held by the sovereigns; holders of sovereignty. Roger Struton, A Dictionary of Political Thought (Berkshire, 1982), 32, 366, 441.

208 Divine sovereignty can be seen in polytheism as well. In there we may speak of the monarchial divine sovereignty of one god who is more or less exalted above the others. In Chinese religion Tien or Shang Ti possesses an absolute pre-eminence over all gods and spirits. In Vedic religion the gods in succession are exalted by the worshippers in the type of piety. Even in Zoroastrian dualism Ahura Mazda is assured of final triumph. A similar monarchy position was attained among the Babylonian gods by Marduk, and the Assyrian by Ashur. The composite deity among Re was in like manner exalted in Egyptian theologyin the form of şdolatry. Tendency to raise one god over others may be regarded as the movement from polytheism towards monotheism. In the monotheistic religions the divine sovereignty means not exaltation above other gods, but complete power over nature and man in the form of monolatry. See Alfred E. Garvie, Encyclopedia of Religion and Ethics, XI/757.

209 The word "sovereignty" became popular in theological usage after John Calvin, French Reformer, 1509-1564. A.A. North, New Catholic Encyclopedia, V:XIII, 487. 
kingdom" in the territorial sense. ${ }^{210}$ "Yəhwâ has established His throne (kisə)

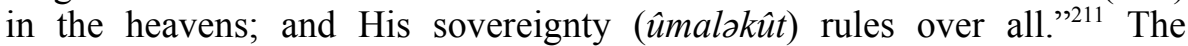
kingdom (melukhah) belongs to Yahwa: "For the kingdom is of 'el-yəhwâ, and He ruleth among the nations." 12 The sovereignty or kingdom (Malkuth) of Yahwa means, as the sole sovereign His exclusive right to exercise supreme political; that is executive, legislative and judicial authority over a geographic region and a group of people. HB clearly propounds yahwa's functions of these: "For Yahwa is our judge ( $\breve{s} \bar{o} f \partial t \overline{e n} \hat{u})$, Yahwa is our

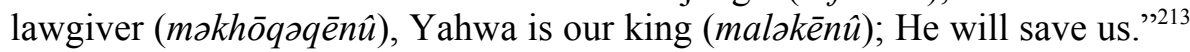
The advent of the final kingdom of Yahwa will be a source of great joy, not only for Israel, Sion ${ }^{214}$ and the cities of Juda, ${ }^{215}$ but also for the heavens and the earth, and will bring perfect joy to the whole world. ${ }^{216}$ This is a heavenly character of Yahwa's eschatalogical reign. His dominion is universal that shall not be taken away: "And there was given Him dominion (umaləkhîu), and glory, and a kingdom, that all peoples, nations, and languages should serve Him. His dominion is an everlasting dominion, which shall not pass away, and His kingdom which shall not be destroyed."217

Greek word used for God is kurios "Lord" may express concept of sovereignty and kingdom. Another term for "kingdom" in the New Testament is a translation of the Greek word "basileia" meaning "reign, rule, kingship" which in turn is a translation of the words "malkuth in Hebrew and "malkutha in Aramaic." Basileia denotes the territory ruled by a king, ${ }^{218}$ in the NT, but contrary to the Hebrew Bible, do not define kingdom of Lord by territory but by dominion. ${ }^{219}$ The only meaning that "kingdom or sovereignty of Lord" could have in the territorial sense would be in regard to the whole

210 See Chronicles, Esther, Daniel. M.J. Cantley, New Catholic Encyclopedia, VIII/191.

211 Ps. 103/19; Dan 7/27.

212 Psalms 22/28.

213 Isaiah 33/22.

214 Zion Sunny; height, one of the eminences on which Jerusalem was built. It was the south-eastern hill of Jerusalem. When David took it from the Jebusites he built on it a citadel and a palace, and it became "the city of David." In the books of Psalms and Isaih Zion was sometimes used to denote Jerusalem in general, and sometimes God's chosen Israel.

215 Ps $95(96) / 8$.

216 Ps $95(96) / 11 ; 96(97) / 1 ; 97(98) / 7$.

217 Daniel 7/14. Daniel book of the Bible. It combines "court" tales, perhaps originating from the 6th cent. BC, and a series of apocalyptic visions arising from the time of the Maccabean emergency (167-164 BC).

218 Matt 4/8; 12/25-26; Mark 3:24; 6:23; Luke 4:5; 21:10.

219 "The kingdom (basileia) of God" is the sole general phrase expressing the object of Jesus' proclamation. In Matthew is mostly appears as "kingdom of heaven" probably as an artificial restoration of Jewish rabbinic usage. It is a fact that Jesus's contemporaries shared with the rabbinic tradition at least a political coloration of the concept. John Pairman Brown, The Encyclopedia of Religion, $2^{\text {nd }}$ ed. V.8/5148. 
universe. ${ }^{220}$ "Thine, O Lord, is the greatness and the power and the glory and the victory and the majesty, indeed everything that is in the heavens and the earth: Thine is the dominion, O Lord."

The Kingdom of Lord or Reign of Lord is a foundational concept and the central theme of Jesus of Nazareth's message in the synoptic Gospels. The phrase occurs in them more than 100 times, and is defined almost entirely by parable. In the NT the expression "kingdom of Lord" usually designates Lord's reign or sovereign rule as king whereby He brings men the blessings of salvation. Sometimes it signifies God's realm over which $\mathrm{He}$ rules as king. The doctrine of the HB helps to understand the language of Jesus in the Synoptics. He proclaims the "kingdom of Lord" and affirms its transcendence through analogies drawn from early kingdoms founded on the doctrine of the HB. Jesus's teaching does not arise in a vacuum, but in the perfect fulfilment of something that was begun in the religious teaching of Israel. Jesus links himself with Hebre Bible: "And he said unto them, These are the words which I spake unto you, while I was yet with you, that all things must be fulfilled, which were written in the law of Moses, and in the prophets, and in the psalms, concerning me.,"222

Jesus used the term "Kingdom of Lord" "223 and described and preaached it through parables. ${ }^{224} \mathrm{He}$ said unto them: "I must preach the kingdom of Lordto other cities also; for therefore am I sent, ${ }^{225}$ "Whosoever shall not receive the kingdom of Lord as a little child, he shall not enter therein."226 "But seek ye first the kingdom of Lord, and His righteousness; and all these things shall be added unto you." 227 "And again I say unto you, It is easier for a camel to go through the eye of a needle, than for a rich man to enter into the kingdom of Lord." 228 "Therefore say I unto you, the kingdom of Lord

220 M.J. Cantley, New Catholic Encyclopedia, VIII/191.

221 I Chron. 29/11,12.

222 Luke $24 / 44$.

223 Luke 10/9. The Gospel of Luke is a synoptic Gospel, and the third and longest of the four canonical Gospels of the New Testament. The text narrates the life of Jesus, with particular interest concerning his birth, ministry, death, and resurrection; and it ends with an account of the ascension. Luke is a companion of Paul. Contemporary scholars generally conclude that the author, probably a Gentile Christian, wrote the gospel about 85-90 AC. As sources, he used the Gospel of Mark (written 65-70 AC). Like the rest of the New Testament, the gospel was written in Greek. Like Mark but unlike Matthew, the intended audience is Gentile, and it assures readers that Christianity is an international religion, not a Jewish sect. See Donald Guthrie, New Testament Introduction (Leicester, England: Apollos, 1990), p. 105; Harris, Stephen L., Understanding the Bible (Mayfield. 1985).Cf. Matta 12/28. Matt 13/24-33, 44-50: Luke 13/18-21.

225 Luk $4 / 43$

226 Mark 1/14.

227 Mat 6/33.

228 Mat 19/24. 
shall be taken from you, and given to a nation bringing forth the fruits thereof." 229

The kingdom Jesus taught is universal; it would come when the word of Lord had been addressed to all men. It would grow like a seed, ${ }^{230}$ and Lord's power alone would effect that growth. ${ }^{231}$ Jesus teaches that the kingdom of Lord has come upon you, ${ }^{232}$ also affirmed that the reign of Lord is already present. ${ }^{233}$ "And saying: The time is fulfilled, and the kingdom of Lord is at hand; repent ye, and believe the gospel. ${ }^{234}$

Lord showed His sovereign rule in the New Testament as well, first in the experience of young woman when He simply stepped into her life and told her what He was going to do. And in the sixth month the angel Gabriel was sent from Lord unto a city of Galilee, named Nazareth, to a virgin espoused to a man whose name was Joseph, of the house of David; and the virgin's name was Mary. He claimed to have the power to do what $\mathrm{He}$ desired: "For nothing will be impossible with Lord," said the angel. Lord knew Mary, and He knew what her future held because He had plans for Her. And He faithfully fulfilled His promises, according to His will, as Mary knew He would. ${ }^{235}$

The Qur'anic word mulk and malakût meaning; reign, royal power, sovereignty, absolute dominion, kingship, and kingdom over everything, as the Hebrew Bible word malakîth and Malkuth synonimously means. ${ }^{236}$ Mulk, from a Semitic root $m-l-k$, is common to both Arabic and Hebrew. Another word in the Qur'an denoting ruling and reigning is $h u k m$.

Qur'an uses the term mulk for earthly or secular political powers as well, even for non-monotheist kings: Nimrud endeavours to claim for himself God's mulk against Abraham. ${ }^{237}$ "And Pharaoh proclaimed among his people, saying: "O my people! Does not the dominion of Egypt (mulk $m i s r$ ) belong to me?"238 The term used for David and Solomon ${ }^{239}$ who

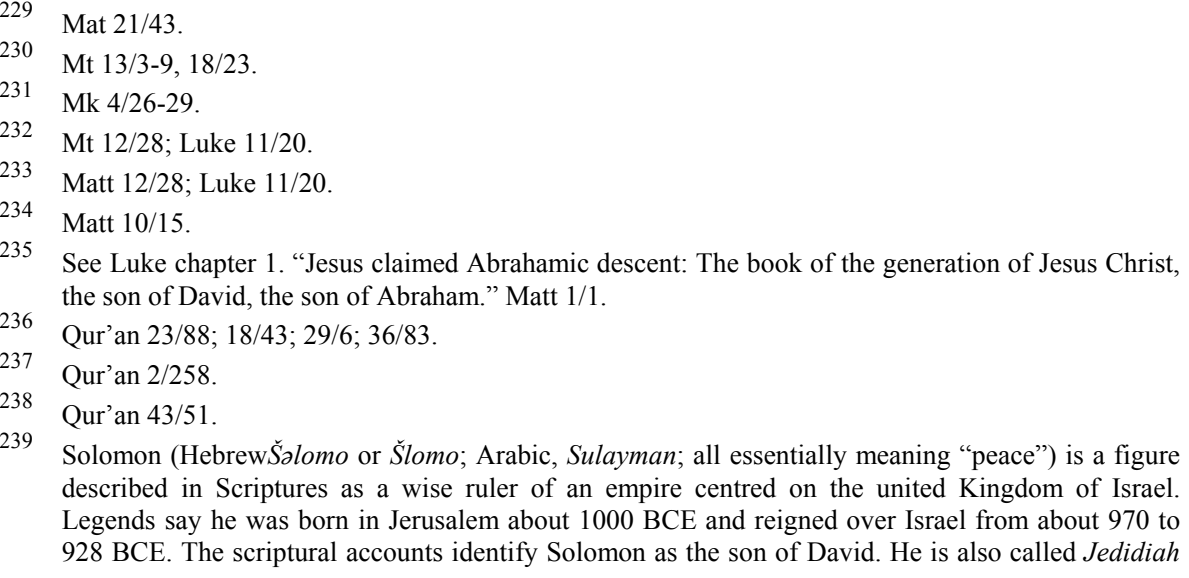

239 Solomon (HebrewŠalomo or Šlomo; Arabic, Sulayman; all essentially meaning "peace”) is a figure described in Scriptures as a wise ruler of an empire centred on the united Kingdom of Israel. Legends say he was born in Jerusalem about $1000 \mathrm{BCE}$ and reigned over Israel from about 970 to 928 BCE. The scriptural accounts identify Solomon as the son of David. He is also called Jedidiah 
contain religious kingship too is mulk: "By Allah's will they routed them; and David slew Goliath (Jâlût); and Allah gave David the sovereigntykingship (mulk),"240 "They followed what the Satan recited over Solomon's kingship (mulk),"241 "Solomon prayed for kingship (mulk)": He said, "O my Lord! Forgive me, and grant me a kingdom which will not belong to another after me." 242 The next verse is well versed to define the term mulk: "Their Prophet said to them: "Allah hath appointed Saul (Tâlutt)" ${ }^{243}$ as king over you." They said: "How can he exercise sovereignty (mulk) over us when we are better fitted than he to exercise kingship (mulk), and he is not even gifted, with wealth in abundance?" He said: "Allah hath chosen him above you, and hath gifted him abundantly with knowledge and bodily prowess: Allah granteth His kingship (mulk) to whom He pleaseth." ${ }^{244}$

The fundamental principle, that ultimately all political authority belongs to Allah and $\mathrm{He}$ is the Lord of Sovereignty, is mentioned in different ways in the Qur'an. Qur'an employes for Allah the same term "mulk": "Blessed be Allah in whose hands is the sovereignty (mulk)," 245 "Possessor of sovereignty (mâlik al-mulk)." 246 "Knowest thou not that to Allah belongeth the dominion (mulk) of the heavens and the earth?"247 Allah has absolute dominion (melekut) over everything. ${ }^{248}$ Allah has the same mulk in the next world. ${ }^{249}$

in the Tanakh, and is described as the third king of the United Monarchy, and the final king before the northern Kingdom of Israel and the southern Kingdom of Judah split; following the split his patrilineal descendants ruled over Judah alone. King Solomon is one of the central Biblical figures in Jewish heritage that have lasting religious, national and political aspects. As the constructor of the first temple in Jerusalem and last ruler of the united Jewish Kingdom of Israel from ancient times, until it was re-established in the modern State of Israel. The Qur'an refers to Sulayman as the son of David (Arabic, Dawud), as a prophet and as a great ruler imparted by God with tremendous wisdom, favor, and special powers just like his father, David. The Qur'an states that Sulayman had under his rule not only people, but also hosts of Jinn. It also states that Sulayman was able to understand the language of the birds and ants, and to see some of the hidden glory in the world that was not accessible to common human beings. See Finkelstein Israel; Neil Asher Silberman, David and Solomon: In Search of the Bible's Sacred Kings and the Roots of the Western Tradition. (Free Press, 2006)

Saul (Talut) the first king of the ancient Kingdom of Israel. He reigned from Gibeah for some two decades at the close of the second millennium B.C.

244 Qur'an 2/247.

245 Qur'an 67/1.

246 Qur'an 3/26

247 Qur'an 2/107; 3/189; 5/17, 120; 7/158; 9/116; 24/42.

248 Qur'an 23/88; 18/43; 29:6; 36/83.

$2496 / 73 ; 22 / 56 ; 25 / 26 ; 40 / 16$ etc. 


\section{Creation-Founding a State}

The concept of Yahwa's sovereignty presupposes the fact of His creation, that is, the origination of all the existence; this universe and the Next World by the fiat of Him: "In the beginning Elohim created the heavens and the earth." ${ }^{250} \mathrm{He}$ is the first and the last, the Alpha and Omega; He is the beginning of this creation. That is He created His kingdom, the universe; His state: "Then He laid the foundations and founded His state." Hence He has the right to have sovereignty in His geographic region, the domain, ${ }^{251}$ then making it suitable for the creatures to live. ${ }^{252}$ Like an absolute sovereign Elohim creates by giving orders, and it begets. His hands stretched out the universe and He commanded: "And Elohim said, "Let there be light. And there was light." 253 Then Yahwa Elohim started to create man, as His subjectpeople of His state. ${ }^{254} \mathrm{He}$ deserves to be a king also because He feeds His people. ${ }^{255}$ The fact that creation distinguishes Yahwa as the true God from the other gods. ${ }^{256}$

In NT the work of creation of God has been acknowledged. All things were made by Him; and without Him was not anything made that was made. In him was life; and the life was the light of men." ${ }^{257}$ The one great end in the work of creation is the manifestation of the glory of the Creator. ${ }^{258}$ The work of creation is attributed to the Trinity; the Father: "But to us there is but one God, the Father, of whom are all things, and we in him; and one Lord Jesus Christ, by whom are all things, and we by him, ${ }^{6259}$ the Son ${ }^{260}$ and the Holy Spirit. ${ }^{261}$

Creation has an equal importance in the Qur'an as well that does allocate a substantial place to it. There is a relation between the creation and sovereignty: "Allah is the Creator of all things, and He is in full control of all

Genesis $1 / 1$.

Genesis 1/1; 2 Kings 19/15; Job 26/13; 38/4; Prov. 3/19; Isa. 42/5; 44/6; 45/12; 66/2; Jonah 1/9.

Genesis $1 / 29,30$.

Genesis $1 / 3$.

Genesis 2/7

Genesis Chapter 1.

256 Traditions of the creation of the gods are found among the records of ancient Eastern nations. A peculiar interest belongs to the traditions of the Accadians, the primitive inhabitants of the plains of Lower Mesopotamia. These within the last few years have been brought to light in the tablets and cylinders which have been rescued from the long-buried palaces and temples of Assyria. They bear a remarkable resemblance to the record of Genesis. Also see Isa 37/16, 40/12, 40/13, 54/5; Psa 96/5; er $10 / 11-12$.

258 Joh $1 / 3-4$

1 Coll 1/16; Rev 4/11; Rom 11/36

259 Joh 1/1-3; 1 Collosians 8/6.

260 1Collosians 1/13-17.

261 Gen 1/2; Job 26/13; Psa 104/30. 
things." ${ }^{" 262}$ Hence He deserves to be the sole sovereign of them. "To Allah belongs the dominion of the heavens and the earth. He creates what $\mathrm{He}$ wills." 263 "His are the Creation and the Command." ${ }^{264}$ Creation is also the reason for Allah's defiance to other deities. Other gods does not deserve sovereignty because they are able to create nothing. ${ }^{265}$ Qur'an like Hebrew Bible created a nation and a state by utilizing the creation power of Allah.

\section{Delegation of Sovereignty; Indirect Rule and Divinial Kingdom on the Earth}

The Biblical prophets were not religious personalities such as priests. They wanted a revolution to change the established system, both the religious and the political. They had no power but used God's power. Hence in order to make the oracles of the peophets are the pronouncements of His royal majesty. ${ }^{266}$ God had to delegate power to them. They made Yahwa delegates power to prophets, prophet-kings, kings and priests as His deputy or vicegerent which He speaks and acts through them. The basic reason they put forward for Yahwa authorizes man by delegating political authority is: "And Yahwa said, Let us make man in our image, after our likeness; and let them have dominion," 267 First of all they convinced people that God's first and foremost aim is to make the prophets accepted by the people. Hence Prophets urge the people to obey Yahwa, but this obedience is abstract, because by obeying Yahwa people obeyed the prophets and this made it a concrete obedience. Then Yahwa ordered the prophets to be acting as a ruler at the same time, by commanding the people to obey them. "And Moses cried to Yahwa, saying, What shall I do with this people? Yet a little, and they will stone me!", ${ }^{268}$ Yahwa said to Moses: "And now go, lead (mala'ākhî) the people whither I have told thee." ${ }^{269}$ In this meaning the term kingdom appears first time when Yahwa said to Moses: "And ye shall be to me a kingdom (malekhet) of priests, and a holy nation."270 Through delegation of divinial power these personalities got the credit amongst their people of

\footnotetext{
Qur'an 4/126; 10:31; 13/16;31/22; 33/27; 34/21; 39/21, 62; 55/29.

Qur'an 42/49.

Qur'an 7/54.

Qur'an 62/73; 16/20;25/3; 16/20.

Jer 46/18; 48/15; 51/57. Jeremiah; comprising a collection of prophetic oracles attributed to Jeremiah, a prophet who preached (c.628-586 BC) in Jerusalem under King Josiah and his successors.

267 Geneis $1 / 26 ; 3 / 5$

268 Exodus $17 / 4$.

269 Exodus $32 / 34$

270 Exodus 19/6.
} 
being the persons can speak to Yahwa, and He speaks to them. ${ }^{271}$ They became social voice of His authority. Yahwa speaks and rules through these representatives.

The principal concern in delegation power is that every vassal was to secure his sole allegiance to his suzerain, since all the political powers other than Yahwa's is subsidiary and they are bound to obey Him. God commands the prophets and they accomplish. Prophets do whatever they do under the command of God, as is the case for Moses in behaving to Pharaoh and Israelites. ${ }^{272}$ Moses do what God commanded him: And Aaron and his sons did all things that Yahwa had commanded by the hand of Moses. ${ }^{273}$ That is the prophets have to acknowlege Yahwa's sovereignty. Moses said: "Thine, O Yəhwâ is the greatness, and the power, and the glory, and the victory, and the majesty; for all that is in the heaven and in the earth is thine; thine is the kingdom (hamma məlākâ), O Yəhwâ, and thou art exalted as head above all." 274

The kings and envoys could only be chosen by Yahwa ${ }^{275}$ through the covenants ${ }^{276} \mathrm{He}$ makes with His people, the most important being the Mosaic covenant instituted on Mount Sinai. ${ }^{277}$ After having established the authority of the prophets over the people there came a time in the history of that people when a king was demanded, that they might be like other nations. The prophet Samuel remonstrated with them, but the people cried out, "Nay, but we will have a king over us." The misconduct of Samuel's sons. Thus

271 This stance enables the prophets to be the charismatic leaders of their people.

272 Exodus 6

273 Leviticus 8/36.

2741 Chron. 29/11.

275 Deut $17 / 14$

276 Covenant meaning a solemn contract, oath, or bond, is the customary word used to translate the Hebrew word berith, (Standard Hebrew borit) as it is used in the Hebrew Bible, thus it is important to all Abrahamic religions. In a religious context, covenants have been made by God with humanity. Yahwa made a covenant with Abraham that He would bless Abraham's descendants making them more numerous than the stars. Genesis $8 / 9$ God made a covenant with most of the Israelite prophetkings. The Davidic covenant, found in 2 Samuel 7, establishes David and his descendants as the rightful kings of Judah. In Christian theology, the Davidic covenant is an important element of Jesus's claim to be the Messiah. Yahwa's covenants with the Israelites are foundational to the Torah, as well as to the Tanakh in general, and form the grounds for the claim that the Israelites are Yahwa's "chosen people." According to the terms of these covenants, the Israelites were told that they must worship Yahwa and obey His Commandments in order to receive spiritual and temporal blessing and avoid exposure to the effects of the curse. More specifically, a covenant, in contrast to a contract, is a one-way agreement whereby the covenantor is the only party bound by the promise. God delegates authority of kingship on the earth on a king with a covenant made between Him and the anointed king. A covenant, in its most general sense, is a solemn promise to do or not do something specified. This covenant does not represent an election of the king. It is essentially a religious covenant, and the limitation of the king's authority consists the king's duty to observe the law of the Lord Deut 17/19ff; cf. 1 Kings 3/14; Psa 132/11-12. 
David's anointment as king by the prophet Samuel ${ }^{278}$ was the immediate cause of this demand. ${ }^{279}$ This is presented in HB as Yahwa appointed and said to David: "But I will settle him in mine house and in my kingdom (maləkûtî) for ever; and his throne (kisə) shall be established for evermore," 280 David said: "And of all my sons; He hath chosen Solomon ${ }^{281}$ my son to sit upon the throne ${ }^{282}$ of the kingdom of Yahwa (al-kissée malakût yəhwâ) over Israel." 283

This type of rulers are not responsible to the people, but only to Yahwa only. The Hebrew kings did not rule in their own right, nor in name of the people who had chosen them, but partly as servants and partly as representatives of Yahwa, the true King of Israel. ${ }^{284}$ Hence only Yahwa can punish for if they break the covenant, by removing them from His favor. ${ }^{285}$ "Yahwa has appointed him as a ruler over his people; for thou (Saul) hast not kept what Yahwa commanded thee."286 The ruler Yahwa appointed must be the ruler of justice and a suppressor of iniquity. ${ }^{287}$ This means that the

278 Samuel is an important leader of ancient Israel. He was the last of the Hebrew Judges and the firs of the major prophets who began to prophesy inside the Land of Israel. According to the text of the Book(s) of Samuel, he also selected/anointed the first two kings of the Kingdom of Israel; King Saul and King David. Around 1025 BCE Samuel anointed Saul ben Kish from the tribe of Benjamin as the first king of the Israelites, supposedly in 1020 BC. His successor as the second king of Israel, David c.1006 BC, was responsible for consolidating the monarchy and creating the first Hebrew state.

$279 \mathrm{Sa} 18 / 5$

$2801 \mathrm{Chr} .17 / 14$.

281 Solomon means Peaceful, (Heb. Shelomoh), David's second son by Bathsheba, i.e., the first after their legal marriage (2 Sam. 12). He was probably born about 1035 B.C. (Ch1 22/5; 29/1) in Jerusalem. He succeeded his father on the throne in early manhood, probably about sixteen or eighteen years of age and reigned over Israel from about 970 to $928 \mathrm{BCE}$. The throne of Solomon is described at length in $1 \mathrm{Kg} \mathrm{10/18.}$

$2831 \mathrm{Chr} 28 / 5$. The name of Israel conferred on Jacob after the great prayer-struggle at Peniel (Gen $32 / 28$ ), because "as a prince he had power with God and prevailed." This is the common name given to Jacob's descendants. The whole people of the twelve tribes are called "Israelites," the children of Israel, (Jos 3/17; Jos 7/25; Jdg 8/27; Jer 3/21), and the "house of Israel" (Exo 16/31; 40/38). This name Israel is sometimes used emphatically for the true Israel (Psa 73/1; 45/17; 49/3). After the death of Saul (Tâlût) the ten tribes arrogated to themselves this name, as if they were the whole nation $(2 \mathrm{Sa} 2 / 9,10,17,28 ; 3 / 10,17 ; 19 / 40)$, and the kings of the ten tribes were called "kings of Israel," while the kings of the two tribes were called "kings of Judah." After the Exile the name Israel was assumed as designating the entire nation.

Sa1 10/1.

285 I Samuel 13/14; Dan 7/27.

I Samuel 13/14. According to the first book of Samuel, due to his disobedience to God, Saul's reign was curtailed and his kingdom given to another dynasty. David and Saul had earlier become bitter enemies. The Bible portrays Saul as having died in battle against the Philistines; David in this war had sided with the Philistines against Saul.

Isa 9/6-11 etc. 
worldly kingdom of Israel is Yahwa's indirect rule, hence the political throne is of His. ${ }^{288}$

Religious concept in Biblical Israel regarded the delegated king as a son of God, as a divine figure. In Nathan' $\mathrm{s}^{289}$ vision concerning David and his dynasty, the prophet speaking in the name of the Lord, says about each of the future kings of David's line, "I will be to him for a father, and he shall be to me for a son." "290 "You are my son, this day I have begotten you." "291 "Your throne is God's, for ever and ever." ${ }^{292}$ This religious concept in Biblical Israel regarded the delegated king as a son of God and a divine figure.

By basing on HB the proclamation of Gospel of Mark in making Jesus as the Son of God and taking his phrase of "the kingdom of Lord has come near, ${ }^{, 293}$ has been interpreted as that already the leaven of the kingdom of Lord is at work in this world through the man. ${ }^{294}$ The incident can be read to support a position of the "Kingdom of Christ." In fact Jesus allowed others to acclaim him a basilikos, meaning "king" as his Lord. ${ }^{295}$ The Son Jesus Christ acts as his Father, Lord God: "The Son of man shall send forth his angels, and they shall gather out of his kingdom all things that offend them and which do iniquity; and shall cast them into a furnace of fire; there shall be wailing and gnashing of teeth." ${ }^{296}$ However Jesus' kingship is not of this world. ${ }^{297}$ He said: "My kingdom is not of this world. If my kingdom were of this world, my servants would have been fighting, that I might not be delivered over to the Jews. But my kingdom is not from the world either."298 But Jesus announced that his religious teachings were separate from earthly

288 David said: "And of all my sons, He has chosen Solomon my son to sit upon the throne of the kingdom of Yahwa over Israel." I Chron 28/5. "And Solomon sat on the throne of Yahwa as king instead of David his father, and prospered; and all Israel obeyed him." I Chron 29/23. "Blessed be Yahwa thy God, who delighted in thee, to set thee on his throne, to be king to Yahwa thy God! Because thy God loved Israel, to establish them for ever, therefore did he make thee king over them, to do judgment and justice." II Chronicles 9/8.

289 Nathan the Prophet was a court prophet who lived in the time of King David and his wife Bathsheba. He once came to David to reprimand him over his committing adultery with Bathsheba while she was the wife of Uriah. His actions are described in the Books of Samuel, Kings, and Chronicles (see especially, 2 Samuel 7/2-17, 12/1-25. Nathan wrote histories of the reigns of both David and of Solomon (see 1 Chronicles 29/29 and 2 Chronicles 9/29, and was involved in the music of the temple. 2 Chronicles 29/25.

Psalms 2/7-8.

Psa $45 / 7$.

3 Mark 1/14-15.

294 Luke 13/20.

295 Matt 21/5; 19/38; John 12/13, 15.

296 Mat 13/42-42.

297 John 18:36.

298 John 18/36. 
political activity. All three synoptic Gospels portray Jesus as saying: "Then render to Caesar the things that are Caesar's, and to Lord the things that are Lord's." Jesus gave this answer to Pharisees who asked him whether it is lawful to pay taxes to Caesar or not; Jesus begins by asking them whose portrait appears on a Roman coin. ${ }^{299}$ He seemed to recommend obeidence to the Roman Emperor. The earthly phase of this kingdom turns to be Church of Christ, ${ }^{300}$ that visible society of which Christ is the head. The Church is Christ's kingdom. Jesus is not only the founder of this Church-Kingdom, but its Lord and Ruler. ${ }^{301}$ In this way, it is closely linked with the ancient Israelite theocracy; a chosen people ruled by God through His chosen emissaries. And realization of God's kingship over souls, like perdurance of the Israelite theocracy, is in proportion to man's union with the God-Man in faith, love, and obedience. ${ }^{302}$

The following verses denote that Allah delegates sovereignty: "Possessor of sovereignty (mâlik al-mulk), You give sovereignty (mulk) to whomever You choose, and You take it back." 03 "Allah gives His sovereignty-kingship (mulk) to whom He wishes." ${ }^{304}$ Allah by making the Adam as His vicegerent (Khalifa) on the earth He had from the outset of the creation of men, delegated practically political sovereignty to the humans on the earth. ${ }^{305}$ And then onwards $\mathrm{He}$ legitimized by taking over the responsibility of the appointments all the kings of the Israelites, no matter how they came to the power. Qur'an by quoting Hebrew Bible saying: "But We had already given the people of Abraham the Book and Wisdom, and conferred upon them a great kingdom. ${ }^{\text {"306 }}$ Moses said: "Allah produced prophets among you, made you kings (mulukk), and gave you what He had not given to any other among the peoples." ${ }^{307}$ Joseph thanks Allah in prayer for the mulk He has given him. ${ }^{308}$ "O David! Surely We have made you a vicegerent on the earth." "309 "And remember when He made you rulers after Noah's people." " "And David slew Goliath (Jâlût) and God bestowed on

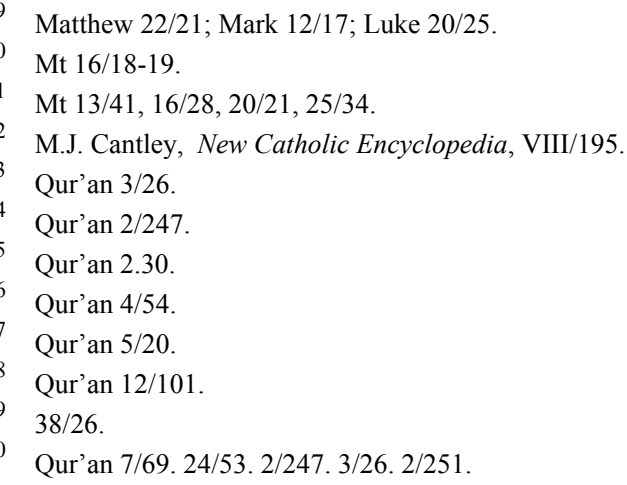


him political power and wisdom and taught him what he willed." 311 Solomon was the son of David, He succeeded his father. He too was a prophet. He was fond of power and magnificence so he supplicated to Allah: Solomon prayed: "O my Lord! Forgive me, and grant me a kingship (mulk) which will not belong to another after me." 312 Qur'an mentiones no ceremonies of enthronment neither for Allah during His enthronment nor for His vicegerants whom He delegated political power.

\subsection{Anoitment During the Induction of the Vicegerents}

The practice of anointing with perfumed oil was common among the Hebrews. It was the custom of the Jews in like manner to anoint themselves with oil, as a means of refreshing or invigorating their bodies ${ }^{313}$ For the Hebrews, the act of anointing was significant in consecration to a holy or sacred use $\mathrm{e}^{314}$ As the human and undivine successor kings are done by their predecessors Yahwa was made anointing the personalities He delegated ruling power. Yahwa's vassals; Prophets, high priests and kings were anointed and called "the anointed one "messiah" (məšîhwō). ${ }^{315}$ They are the sons of Yahwa ${ }^{316}$ and were annointed by Him. ${ }^{317}$ Anointing them was equivalent to crowning them. ${ }^{318}$ Yahwa said: "And I have anointed my king (maləkî) upon Sion, the hill of my holiness (qādəšî)." ${ }^{319}$ Cyrus ${ }^{320}$ is His annointed to fulfil His purpose. ${ }^{321}$ "And shalt take the anointing oil, and pour it on his head, and anoint him, and with sacrifice.",322 "And Moses took of the anointing oil, and of the blood that was on the altar, and sprinkled it on Aaron, on his garments, and on his sons, and on his sons' garments with him; and hallowed Aaron, his garments, and his sons, and his sons'

311 Qur'an 2/231. Goliath (Jalût) was the chief of the Philistines, an infidel people of Palestine, who continually harrassed the Israelites, the followers of Judaism. Saul (Talut), the King of the Jews, fought against them, and a brave young man David, from his army, slew Goliath. After the death of Saul, David became the King of the Jews. Qur'an 38/26.

312 Qur'an 38/35-6.

313 Deu 28/40; Rut 3/3; Sa2 14/2; Psa 104/15, etc.

314 Exodus 30/26; Leviticus 4/3-5, 4/16; 6/20; Psalm 132/10.

315 Exodus 29/29; Psalm 2/2; Leviticus 4/3; 1 Kings 19/16; 1 Chronicles 16/22; Psalm 105/15.

3162 Sam 7/14.

317 Sam 24/10; Psalm 89/39.

3181 Samuel 16/13; 2 Samuel 2:4, etc.

319 Psalm 2/6.

320 Cyrus II of Persia and Cyrus the Elder (590 or 576-530 BC), was the founder of the Persian Empire under the Achaemenid dynasty. As leader of the Persian people in Anshan, he conquered the Medes and unified the two separate Iranian kingdoms; as the king of Persia, he reigned over the new empire from $559 \mathrm{BC}$ until his death

321 Is. $45 / 1$.

322 Exodus 29/7, 11. 
garments. ${ }^{323}$ David was anointed as king by the prophet Samuel. The throne of David's son Solomon is described at length in HB. ${ }^{324}$ After David, the kings of non-Davidic descent has been problematic but yet they were deemed legitimate monarchs provided they were appointed by a prophet, fought in the battles of the land, and conducted in accordance with the precepts of the Torah. Whereas kings of Davidic descent were annointed with olive oil, the others with balsam oil.

NT recognizes the custom of anoitment mainly in religious sense: "But thou, when thou fastest, anoint thine head, and wash thy face, ${ }^{325}$ but not in political terms, since Lord, through Jesus Christ appointed no political rulers. By utilizing the "promised Anointed" or Messiah of $\mathrm{HB},{ }^{326}$ because $\mathrm{HB}$, he was anointed with the Holy Ghost. ${ }^{327}$ Jesus of Nazareth proclaimed himself as this anointed One. ${ }^{328}$

Qur'an uses the term anoitmnet for ritual purposes. ${ }^{329}$ However Qur'an recognized divinial anointment of Jesus Christ as "the anointed" (al-masîh) of Allah. ${ }^{330}$ We have not been able to trace any track in It mentioning political annointment during the enthronment and induction of Allah's vicegerants $\mathrm{He}$ delegated political power. This may be because It wanted to finilize the anoitment by Allah with Jesus Christ. As a matter of fact Muhammad, the prophet of Qur'an annointed neither himself nor anybody else he granted political power during their induction. This indicates that Qur'an is against mixing and degrading the religion and the deity with the mundane political matters. Furthermore it spent an endeavour to get rid of the ceremonies and make the religion purely for God.

\section{B. The Sovereign in The Scriptures}

Sovereignty is held by a sovereign ${ }^{331}$ who is the supreme ruling, lawmaking and judgement authority, subject to no other. This authority usually was a king during the compilation of the Hebrew Bible. The term king (melekha) in this Scripture is very generally used to denote one invested with supreme

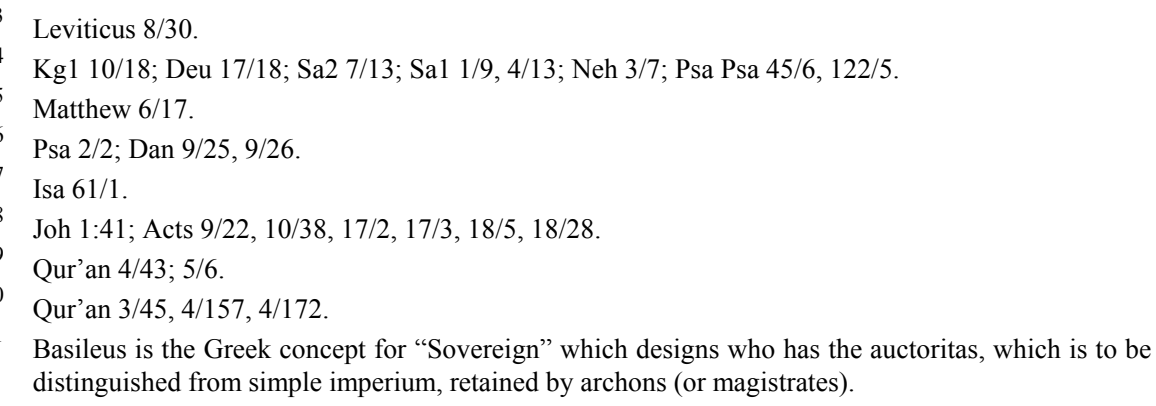

Basileus is the Greek concept for "Sovereign" which designs who has the auctoritas, which is to be distinguished from simple imperium, retained by archons (or magistrates). 
sovereign, whether extensive or limited, ${ }^{332}$ divine or secular. ${ }^{333}$ It has been used for Jaqob, ${ }^{334}$ for the king of Palestine, ${ }^{335}$ and Egypt, as for Yahwa. ${ }^{336}$

In the New Testament Greek word used for sovereign is dunastes means "king, ruler" from dunamis "power." 337 The Roman emperor is spoken as the king when Jesus was born in Bethlehem of Judaea in the days of Herod Antipas was the king,. ${ }^{338}$ This title is applied to God: "Now unto the King eternal, immortal, invisible, the only wise God, be honour and glory for ever and ever. Amen. ${ }^{339,,},{ }^{340}$ and to Christ, the Son of God. ${ }^{341}$

Qur'anic word for the sovereign king is melik (pl. mulukk) stemming from the old Semitic root $m-l-k .^{342}$ As a kingly title, the term appears repeatedly in the Qur'an. It mentiones several historical and legendary kings (mulukk). Allah uses the term melik when He has sent Saul (Tâlût) as a king over Israelites: "Their Prophet said to them: Allah hath appointed Saul as king (melik) over you." ${ }^{343}$ The term melik is used for Egyptian Pharaoh: "So the king (al-melik) said: Bring ye him unto me. But when the messenger came to him, (Joseph) said: "Go back to thy lord ( $r a b b)$, and ask him.",344 The term king used for any king: "For there was after them a certain king (al-melik) who seized on every boat by force." 345

\footnotetext{
3321 Sa 8/7; Isa 33/22.

333 Melekh “King” Psa. 5/2, 29/10, 44/4, 47/6-8, 48/2, 68/24, 74/12, 95/3, 97/1, 99/4, 146/10; Isa. 5/1, $5,41 / 21,43 / 15,44 / 6 ; 52 / 7,52 / 10$.

334 “And kings ( $\hat{u}$ məlākhîm) shall come out of thy loins." Genesis 35/11.

335 Genesis 26/1.

336 Exodus $1 / 8$

337 I Tim. 6/15.

338 Mat 2/1, 14/9; Mark 6/22. Herod Antipas (20 BC-c. 39 AD) was an ancient leader (tetrarch, meaning "ruler of a quarter") of Galilee and Perea. He is best known for his role in the events surrounding the Passion of Jesus.

339 Amen is Hebrew word means firm, and hence also faithful. Rev 3/14. It is frequently used by God to give emphasis to His words, where it is translated "verily." It is used as an epithet of the Lord Jesus Christ. Rev 3/14. It is found singly and sometimes doubly at the end of prayers to confirm the words and invoke the fulfillment of them. Psa 41/13, 72/19, 89/52. It is used in token of being bound by an oath. Num 5/22; Deu 27/15; Neh 5/13, 8/6; Ch1 16/36. In the primitive churches it was common for the general audience to say "Amen" at the close of the prayer. Co1 14/16.

Ti1 1/17.

341 Ti1 6:15-16; Mat 27/11.

342 The Hebrew equivalent of melik is melekh; Aramaic malkâ; Akkadian malku; Assyrian malku and maliku which signifies "possession" and "rule" and "government." A. Ayalon, "Malik" Encyclopedia of Islam, $2^{\text {nd }}$ ed. VI/261.

343 Qur'an 43/47.

344 Qur'an 12/50

345 Qur'an 18/79.
} 


\section{Sovereign Deity}

Since the compilation of the Hebrew Bible stretched more than a millennium, occurrence of development and replacement of the term king of Yahwa is inevitable. But our interest lies within the political kingship of Yahwa, not the changes in the concept. The theme of "Yahwa, the ruling Lord" is running throughout the HB. The Hebrew concept of Yahwa is a King. ${ }^{346}$ That is Yahwa is a King-God. This concept is asserted some 50 times in the HB, most frequently in the Psalms. ${ }^{347}$ King is applied to Yahwa by the earliest literary prophets during the 8 th and 7 th centuries BC, such as Amos, Hosea and Isaiah. In here Yahwa is given present and universal kingship based on His creation and conservation of the universe as well as His guidance of its history to an ultimate destiny. For example Isaiah's vision of Yahwa as king appears as: "For mine eyes have seen the King, (melekhə) Yahwa of hosts." "348 "Yahwa is King for ever and ever (yəhwâa meleka 'wōlām wa' 'ed)." "349 "Who is this King of glory? Yahwa strong and mighty." 350

Yahwa's Kingship (malkuth) in Hebrew Bible has been used in two basic usages; as king of gods ${ }^{351}$ and the world, and king of Israel. According

346 The term "king" in the Biblical frame of reference is similar to the Ancient Near East, where generally a governor and a ruler is designated, usually the sole authority over his subjects. This term is used to designate the rulers of great empires such as Egypt, Assyria, and Persia; rulers of nationkingdoms such as Moab, Edom, and Israel; and the rulers of city-states, such as Tyre, Hazor, and Jericho. Occasionally the term "king" is used to designate a tribal chief, or the chief of tribes. Although the status of the monarch and the concept of monarchy are not identicalin the various cultures, but the general notion of the nature of monarchy and of the figure of the king in the various cultures of the Ancient Near East have much in common. All shared the view that there was a direct relationship between the king and the deity. In many of the Ancient Near Eastern cultures the monarch was seen as part of the eternal order. In Egypt the monarchy was regarded as an essential element in the order of creation. The monarchy was divine, as the naturalorder of things is divine. In Mesopotamia, in the view that finds expression in the Sumerian kings list, the monarchy was introduced from heaven.

347

Psalms 47, 93, 97. To a certain extent, that Tanakh shared the idea common in the ancient Near East that their deity was a king over his people. In the religions of the Ancient Near East the creator-god was generally regarded as "king," both over the world, which was his creation, and over his fellow gods in the pantheon. In Ancient Egypt all the theological schools considered "kingship" as beginning with creation. The worshippers of god Ptah gave him the title of king, while those who ascribed the creation of the world to god Ra spoke of him as the first king of Egypt. In ancient Mesopotamia, as known the creation epic, called Enuma Elish, Marduk, the god who brought the world out of chaos, was given the royal dignity that until then had belonged to Anu, the god of the

Psalm 10/16.

350 Psalm 24/8.

351 In a pantheon, one god can emerge as supreme. Foreample, Enlil, the tutelary god of Sumerian Nippur, who becomes "lord, king, the judge of the universe. Or the Egyptian deity Amun-Re who is the chief lord, and father of the gods, as well as creator of life. Or through the acclamation of one 
to Hebrew Bible the first community of Yahwa, symbolized by Noah's ark, the selection of Sion and the Temple was only a foreshadowing of another community: the new, universal kingdom. Union with Yahwa, originally the prerogative of the children of Abraham became the inheritence of all men. ${ }^{352}$ "For Yahwa is a great god, a great king over all the gods," world. ${ }^{354}$ These phrases implies that Yahwa is aking over the all created order. In the Psalms (mizamwōr) of David (c.1005-970 BC) ${ }^{355}$ Yahwa frequently given the title of "my king": "Hearken unto the voice of my cry, my King (malakî), and my God (we'lōhayy): for unto thee will I pray. ${ }^{356}$

Yahwa is called the king of Israel ${ }^{357}$ first and foremost because it is only a result of His protection that Israel exists as a nation and is assured of political independence from its neighboring enemies.: "Thus saith the Lord (yəhwâ) the King of Israel (yəhwâ melekə-yiśzrā'ēl))." ${ }^{358}$ Because Yəhwâ, not only $\mathrm{He}$ is "the creator of Israel: "I am the Lord, your Holy One, the creator of Israel, your King," 359 but also because he is the bringer of peace and salvation to Sion: "How beautiful upon the mountains are the feet of him that bringeth good tidings, that publisheth peace; that bringeth good tidings of good, that publisheth salvation; that saith unto Sion, Thy God reigneth!"360 Historically, Yahwa being called as "king of Israel" appears in the Hebrew Bible toward the end of the Babylonian Exile. Although God $(Y h w h)$ is particularly Israel's King, in truth His kingdom is worldwide. That is Yahwa of Israel's sovereignty is over all the other gods and kings.

god as king by the others for his victory over the powers of chaos.See J. B. Pitchard, ed. Ancient Near Eastern texts relating to the Old Testament (princeton, 1969).

352 M.J. Cantley New Catholic Encyclopedia VIII/193.

353 Psalms 95/3, Judges 8/23, I Samuel 8/7, Isaiah 41/21. Psalms or Psalter, book of the Bible, a collection of 150 hymnic pieces. Since the last centuries BC, this book has been the chief hymnal of Jews, and subsequently, of Christians.

354 Psalms 47/3, 93/1, 97/1. According to the scholars of the Hebrew Bible, the writers of Hibrew Bible borrowed the term king for YHWH from surrounding cultures. The gods of Assyria and Mesopotamia such as Marduk and Ashur were regularly spoken as kings in relation to their own peoples and to the rest of the world. Like these gods, YHWH as king was the divine enforcer of justice and equity, guardian of the rights of the defensless widow and orphan. Like them as well he controlled the nations of the world and regulated their movements for the benefits of the people to whom he was chosen. S. David Sperling, The Encyclopedia of Religion, V. 6/6.

355 David (c.1005-970 BC) was the second king of the united Kingdom of Israel. He is traditionally credited with the authorship of many of the Psalms. His life and reign, as recorded in the Hebrew Bible's books of Samuel (from I Samuel 16 onwards) and Chronicles, have been of central importance to Jewish and Western culture.

356 Psalm. 5/2, 29/10, 44/4, 47/6-8, 48/2, 68/24, 74/12, 95/3, 97/1, 99/4, 146/10; Isaiah. 5/1, 5, 41/21, $43 / 15,44: 6 ; 52 / 7,52 / 10$.

3571 Sa $8 / 7$; Isa $33 / 22$.

358 Is $44 / 6,41 / 21$.

359 Is $43 / 15$.

360 Is $52 / 7$. 
Greek word dunastes "king" is applied to Lord, that is Kurios is a king, ${ }^{361}$ as well as to Christ, the Son of Lord. ${ }^{362}$ "Saying, Where is he that is born King of the Jews? for we have seen his star in the east, and are come to worship him. ${ }^{363}$ "And Jesus stood before the governor: and the governor asked him, saying, Art thou the King of the Jews?"364 "The King of Kings and Lord of Lords." "T65 "Thou dost rule over all, and in Thy hand is power and might." " "The Lord our God, the Almighty, reigns."

Kingly title, undoubtedly and exclusively is Allah's. He is the king of the humanbeing. ${ }^{368} \mathrm{He}$ is the Holy king. ${ }^{369}$ With a new connotation from the Bible Qur'an introduces a new title for Allah, the "True King": "High above all is Allah, the True King, (melik haq)." ${ }^{370}$ "Then exalted be Allah, the True King. There is no god but He" ${ }^{371}$ This intonation of "True King" mey well be assumed, is to distinguish Allah from the king-God of Hebrew Bible and the New Testament.

\section{Enthronment of the Sovereign Deity}

Throne (Heb. Kiss'e), a royal chair or seat of dignity, an elevated seat with a canopy and hangings, which cover it. It denotes the seat of the high priest in, and of a provincial governor. Yahwa, like human kings have been assigned a throne. Since Yahwa was true king of Israel, the royal throne was called "the

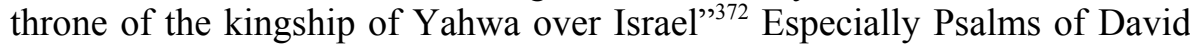
describe Yahwa as terrible, majestic, seated on His Kingly throne, elevated on high, a powerful monarch with limitless authority. Yahwa, His throne is in the heavens," $" 373$

Enthronment ceremony Israelites applied to Yahwa closely follows the ceremonies of the kings of Israel,which underscores the idea of His kingship.

\footnotetext{
1 Tim 1/17.

Mat 2/2.

Mat 2/2.

Mat 27/11

Lk. $1 / 52$.

Rev. 19/6.

Rev. 19/16.

Qur'an 114/2.

Qur'an 59/23; 62/1.

Qur'an 20/114.

Qur'an 23/117.

$1 \mathrm{Chr} 28 / 5,29 / 23$.

Psalm 11/4.
} 
$\mathrm{He}$ is enthroned as He ascents to His throne, ${ }^{374}$ and His ceremony is designed like a king for life, that is once and forever. ${ }^{375}$ "Yahwa abides forever; $\mathrm{He}$ has established His throne." ${ }^{376} \mathrm{He}$ has ceremonial costume: "He hath clothed himself with majesty: He hath girded himself with strength; yea." "377 "Yahwa clothed in majesty and girdled with glory."${ }^{378}$

NT allocates throne to Kurios as It does for the worldly kings: "Heaven is Lord's throne." 379 "Your Father which is in heaven is perfect." "And "And the four and twenty elders and the four beasts fell down and worshipped God that sat on the throne." " 881 "And a voice came out of the throne, saying, Praise our God, all ye His servants, and ye that fear Him, both small and great." 382 NT also assigns a throne to Jesus Christ: "And Jesus said unto them, Verily I say unto you, That ye which have followed me, in the regeneration when the Son of man shall sit in the throne of His glory, ye also shall sit upon twelve thrones, judging the twelve tribes of Israel."

Allah has a Throne ('arsh) as the worldly kings have: "Therefore exalted be Allah, the True King (melik haq); there is no god but He, the Lord of the Throne ("arsh) of Honor." ${ }^{384}$ However contrary to Yahwa, without enthronment and coronation ceremonies He Himself sat on the Throne: "He established Himself on the Throne." 385

\section{Obedience to the Sovereign}

Obedience is a strictly political terminology and the essence of the politics. It is the act of obeying the orders of the rulers. For the imposition of the authority the establishment of obedience is necessary requirement. The foundation of obedience is authority. Hence any offense to obedience of the sovereign is regarded as rejection of his authority.

\footnotetext{
374 Throne (Heb. Kisse), a royal chair or seat of dignity (Deu 17/18; Sa2 7/13; Psa 45/6); an elevated seat with a canopy and hangings, which cover it. It denotes the seat of the high priest in Sa1 1/9; Sa1 4/13, and of a provincial governor in Neh 3/7 and Psa 122/5. 
The word for obedience in Semitic language stems from words meaning "hear" or "hearken." "Hear, O Israel: The Lord our God is one Lord." the HB Israel's hearkening or not hearkening to the "voice" or "word" of Yahwa is a central motif for obedience to Him. Obedience to the authority of Yahwa was exercised within terms of the Covenants, whose content was embraced by the formula; "You shall be my people, and I shall be your God." 387 "Obedience is worth more than sacrifice." 388 Obedience to Yahwa included obedience to the civil authority of His envoys; the prophet-kings or the kings who derived their power from Him. Genesis, the first book of HB begins with creation and carries on with a political terminology of "disobedience of humankind and his punishment." The narrative relates the initial disobedience of Adam and Eve and their punitive consequent expulsion from Yahwa's garden. Obedience to Yahwa included obedience to the delegated authority, which derived its power from God: "The king was chosen by God, ${ }^{, 389} \mathrm{He}$ was the son of God, ${ }^{390}$ he was annointed by Yahwa, ${ }^{391}$ was sacrosanct ${ }^{392}$ and was to be feared as Yahwa Himself. ${ }^{393}$ There are many symbolic forms of obedience required by sovereign deities, namely; love, worship, offerings, and pray etc..

Obedience is concrete realization of the fundemantal commitment to Kurios. NT teaches obedience to Lord: "We must obey Lord rather than men." 394 Jesus Christ is the exemplar and fulfillment of the human obedience to Word of Lord. ${ }^{395} \mathrm{He}$ is a type of obedience, as Adam is the type of disobedience ${ }^{396}$ Christ's obedience to Lord is an obedience even to "death on a cross. ${ }^{" 397}$ In the New Testament, as well as in the HB, obedience to Lord includes obedience to human authority, since true human authority is from Lord. Jesus Christ is the center of NT. It was permeated with obedience to the Word and the Will of the Father. Hence obedience to God is obedience to Christ. The New Testament admonishes pasifism. It included texts that seemed to forbid Christians to resist: "But I say to you not to resist evil; but if one strikes you on your right cheek, turn to him also the other. Love your

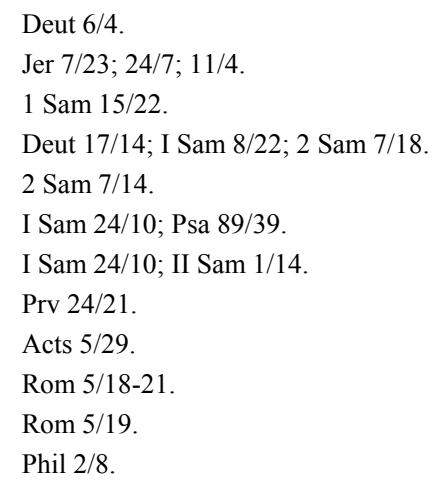


enemies; do good to them that hate you; and pray for them that percecute and caluminate you." 398

The terms Qur'an used having political subordination are the words of "submission and obedience." Qur'anic word for submission is the root $s-l-m$ and for obedince is $t-w$-' $a$. First of all, Allah demands from His subjects a total submission to Him: "Everything in the universe has submitted to Him," "399 "Nay, whoever submits (asleme) His whole self to Allah." 400 To find the right way, submission to Allah is essential, ${ }^{401}$ even from the Messengers of Allah first thing demanded by Allah is submission to Him: "Abraham was commanded to submit Him: "Behold! his Lord said to him: "Submit!" He said: "I submit to the Lord of the Universe." 402 Prophet Muhammed said: "I have been commanded to bow (Islám) to the Lord of the Worlds." ${ }^{403}$ Submission means accepting the system. The penalty for not submitting is the chastisement of Allah. "And follow the best of that which was revealed to you from your Lord, before the Chastisement comes on you of a sudden while ye perceive not." ${ }^{404}$

After submission the obedience to the system follows. "O ye who believe! Obey Allah, and obey the Messenger, and those charged with authority among you." ${ }^{405}$ Qur'an employes the means of punishment and reward to coerce humanbeing to obey. ${ }^{406}$ For those who oppose Allah and His messenger, Allah is most strict in enforcing retribution." 407 "Those who obey Allah and His Messenger will be admitted to Gardens with rivers flowing beneath, to abide therein (for ever) and that will be the supreme achievement." ${ }^{408}$

\section{To Love the Deity}

Love is a form of obedience. Israel is commanded to love God: "And thou shalt love Yahwa thy God ('élōheykā) with all thy heart, and with all thy soul, and with all thy strength." ${ }^{409}$ But this love is reciprocal, going back and

\footnotetext{
Matthew 5:39-44.

Qur'an 3/83.

Qur'an 2/112.

Qur'an 3/20; 72/14.

Qur'an 2/131.

Qur'an 40/66.

Qur'an 39/54.

Qur'an 4/59.

Qur'an 9/74.

Qur'an 59/4.

Qur'an 4/13.

Deut. 6/5.
} 
forth between God and people: "It was because the Lord loved you and kept the oath that He swore to your ancestors, that the Lord has brought you out with a mighty hand, and redeemed you from the house of slavery, from the hand of Pharaoh, king of Egypt." ${ }^{\text {110 }}$ Love of this kind transcends all legalism and transformes Yahwa's sovereignty into something totally different from what human sovereignty can ever be.

Jesus said unto him, "Thou shalt love the Lord thy God with all thy heart, and with all thy soul, and with all thy mind." ${ }^{\prime 11}$ This is the first and great commandment. And the second is like unto it, Thou shalt love thy neighbour as thyself. On these two commandments hang all the law and the prophets." " "Christ must be loved more than one's parents." ${ }^{413}$ NT, in so far as it is linked with the HB law, love is fulfilling the law of God.

Love in general has a significant importance in the Qur'an: "But Allah has endeared the faith to you, ${ }^{, 414}$ and particularly loving Allah Who based the relations with Him on the basis of mutual love: "Soon will Allah produce a people whom He will love as they will love Him." ${ }^{.15}$ Believing in Allah is based on loving Him: "Those who believe are stauncher in their love for Allah." ${ }^{\prime 416}$ Allah stipulated His love with loving His Prophet: "Say: "If ye do love Allah, Follow me; Allah will love you and forgive you your sins." ${ }^{, 417}$ Allah prohibits and punishes loving other deities: "Yet of mankind are some who take rivals to Allah, loving them like loving Allah. Allah is severe in punishment." ${ }^{\prime 418}$ There are many symbolic forms of obedience required by sovereign deities, namely; worship, offerings, and pray.

\footnotetext{
Deut. $7 / 8$.

Mat 22/37.

Mat 22/36-40.

Mt 10/37.

Qur'an 49/7.

Qur'an 5/54.

Qur'an 2/165.

Qur'an 3/31.

418 Qur'an 2/165.
} 